\title{
Capturing stratigraphic and sedimentological complexity from submarine channel complex outcrops to digital 3D models, Karoo Basin, South Africa
}

\author{
J. K. Pringle ${ }^{1,2, *}$, R. L. Brunt ${ }^{1}$, D. M. Hodgson ${ }^{1}$ and S. S. Flint ${ }^{1}$ \\ ${ }^{1}$ Stratigraphy Group, School of Environmental Sciences, University of Liverpool, 4 Brownlow St, Liverpool L69 3 GP, \\ $U K$ \\ ${ }^{2}$ Present address: School of Physical \& Geographical Sciences, Keele University, Keele, Staffs ST5 5BG, UK \\ *Corresponding author (e-mail: j.k.pringle@esci.keele.ac.uk)
}

\begin{abstract}
Submarine slope channel-fills form complicated stratigraphy and lithofacies distributions through repeated phases of erosion and deposition. This provides a challenge to accurate $3 \mathrm{D}$ modelling, particularly in representing lithofacies transitions within sand-poor areas. In this paper, traditional (sedimentary logs, palaeocurrent measurements, architectural panels) and non-conventional technologies (Light Detection and Ranging; Ground Penetrating Radar) were integrated to quantitatively describe lithofacies distributions and sedimentary architectures from two large-scale outcrops, one base of slope, high sandstone content system (Unit B) and one from a mid-slope, more mixed lithology system (Unit C), in the Laingsburg Formation, Karoo Basin, South Africa.

The workflow described in this study combines digital structural restoration and extrapolation of major stratigraphic surfaces, grouped palaeocurrents and architectural geometries observed at outcrop to create $3 \mathrm{D}$ digital models. The model was divided into zones along major stratigraphic discontinuities and populated using lithofacies associations that were adjusted for outcrop rugosity and palaeodispersal direction. Observed channel margin asymmetries, distribution of lithofacies and stacking patterns were all honoured in the digital models.

The Unit C slope-channel system differs from many exposed submarine channels due to the low proportion of sandstone present within the infill. Thin-bedded channel margin lithofacies are preserved through the lateral stepping of channels and allow the correlation of stratigraphy from channel axis to margin and on to overbank areas. In the older, sandier Unit B base-of-slope system, the stratigraphic change in stacking pattern, channel aspect ratio, lithofacies of channel-fills and stratigraphic hierarchy were all captured. This research captured the architectural complexity observed at outcrop to generate more realistic models than could be constructed normally using limited subsurface data.
\end{abstract}

KEYWORDS: outcrop analogue, turbidite, channels, Karoo, modelling

\section{INTRODUCTION}

High quality 3D seismic and 1D well data are the key means of characterizing and calibrating petroleum reservoirs in terms of connectivity and permeability distribution (Weber 1993), especially with continuing improvements in the quality of seismic data and processing methods (Sikkema \& Wojcik 2000; Beyer 2001). Seismic attribute maps extracted from 3D seismic datasets have been used increasingly to identify the geometries of depositional units within submarine channel complexes (e.g. Kolla et al. 2007; Labourdette \& Bez 2010). However, there are still significant resolution issues between seismic datasets and what geologists are able to observe, interpret and quantitatively extract from outcrop analogue studies. For instance, the geo-

Petroleum Geoscience, Vol. 16 2010, pp. 307-330

DOI 10.1144/1354-079309-028 metries of potentially important barriers/baffles to petroleum flow, such as thin, discontinuous shale horizons in sand-rich turbidite systems (Stephen et al. 2001), are not yet resolvable in seismic data. Forward synthetic seismic modelling of outcrop analogue data also supports this observation (Gartner \& Schlager 1999; Schwab et al. 2007; Bakke et al. 2008). Onedimensional borehole images have played an important role in identifying facies distribution and sediment dispersal with submarine channel complexes (e.g. Phillips 1987). Borehole image results have thus greatly assisted in improving 3D seismic dataset interpretations, but again these are 1D and may miss important lateral facies changes, architectural geometry variations and trends. Outcrop analogue research, therefore, can play a key role in addressing these seismic and well-log resolution issues. 
A key requirement for successful integration of outcrop data into a reservoir modelling environment is the extension of the typically $2 \mathrm{D}$ or $2.5 \mathrm{D}$ information into $3 \mathrm{D}$. With this in mind, the acquisition of seismic data over outcrop analogues has been tested, but, to date, has largely proved unsuccessful (Coleman et al. 2000), most probably due to the cemented and commonly fractured nature of ancient rocks, which reduces density and impedance contrasts across lithological boundaries. Ground Penetrating Radar (or GPR) was used successfully to obtain 3D cubes of data behind outcrop cliff-faces (Jol et al. 2003; Pringle et al. 2003; Staggs et al. 2003; Young et al. 2003), albeit at a shallow level, normally a maximum penetration of $10 \mathrm{~m}$ below ground level. Another method of extending outcrop studies into $3 \mathrm{D}$ is the drilling and logging of behind-outcrop wells (Pickering \& Corregidor 2000; Luthi et al. 2006) but resulting data are spatially limited and expensive to acquire.

Outcrop-derived datasets usually need to overcome the inherent subseismic scale, outcrop shape and obliquity problems; although this can be overcome partly by statistical manipulation (see Geehan \& Underwood 1993; Visser \& Chessa 2000; White \& Willis 2000). Spectacularly well-exposed outcrops with a degree of 3D control obtained by modern river incision (e.g. Satur et al. 2000; Hodgetts et al. 2004) are commonly chosen as petroleum reservoir analogues. However, selection through outcrop quality tends to bias towards high sandstone content (high net-to-gross (NTG)) systems, in turn over-emphasizing the importance of these systems. Lower NTG systems often prove just as significant at reservoir scale, but reduced outcrop quality and inherent geological complexity requires a multi-disciplinary approach to gain the same quality of information.

When used accurately, digital outcrop data capture techniques complement traditional geological field-derived datasets and allow integrated 3D reservoir-scale datasets to be compiled. Techniques range from low technology, for example Global Positioning System (GPS) surveys, conventional 1D sedimentary logging (McCaffrey et al. 2005), medium technology, which may include the use of digital aerial and ground-based photogrammetry (see Pringle et al. 2004), or relatively high technology solutions, for example Real-Time Kinematic (RTK), differential GPS (dGPS) surveys (see Hodgetts et al. 2004; Pringle et al. 2006) and high-end, ground-based LIght Detection And Ranging (LiDAR) laser-scanning technologies (Bellian et al. 2005; Olariu et al. 2008; Jones et al. 2009). The resultant highly accurate and detailed quantitative data are then digitally integrated and interpreted, complementing the more traditional geological data capture methods.

This paper demonstrates how a multi-disciplinary approach was used to acquire outcrop data from seismic-scale mixed quality exposures of slope channel complexes in the Permian Karoo basin, South Africa. Both quantitative and qualitative data were collected, integrated and analysed in an accurate spatial context. A key objective is to outline a workflow for the translation of such outcrop information into $3 \mathrm{D}$ reservoir models in an effective and rapid way. This is important for leveraging the maximum benefit from such datasets in terms of being able to explore quantitatively issues such as connectivity, well placement and recovery strategies in subsurface reservoirs of similar architecture (see Hovadik \& Larue 2007).

The outcrops presented include well-exposed high NTG channel axial sections which are juxtaposed with less wellexposed sand-poor units deposited in channel margin environments. Published quantitative outcrop analogue study data from turbidite deposits are numerous but have been largely twodimensional in cross-section and subseismic/sub-reservoir in scale. These include the Tertiary Ainsa II Channel complex in the Spanish Pyrenees (Clark 1995; Cronin et al. 1998) and coastal exposures of the Carboniferous Ross Formation in Western Ireland (Elliott 2000; Lien et al. 2003; Pyles 2008). However, 3D geological models from more rugose turbidite outcrops are starting to emerge (e.g. Falivene et al. 2006; Labourdette et al. 2008; Nilsen et al. 2008; Zanchi et al. 2009).

\section{SKEIDING \& LAINGSBURG RUBBISH DUMP STUDY SITES}

The SW Karoo Basin developed as a retro-arc basin (e.g. Johnson 1991; Cole 1992; Visser 1993; Veevers et al. 1994; Fig. 1a). Post-depositional south-north-directed shortening across the Swartberg range of the Cape Fold Belt propagated into the Laingsburg Karoo, generating a series of east-west-trending folds which gently plunge towards the east (Wickens 1994). One of these folds is the Baviaans syncline in which the study localities are exposed (Fig. 1b). Erosion of the contrasting lithologies within these folds forms a series of prominent topographic ridges, which are separated by mudstone units that form the low ground.

The fill of the Laingsburg depocentre comprises the $1400 \mathrm{~m}$ thick Ecca Group, which is subdivided into the basal mudprone Prince Albert, Whitehill and Collingham formations, in turn overlain by the Vischkuil Formation and the $c .800 \mathrm{~m}$ thick Laingsburg Formation (Wickens 1994). The overlying pro-delta Fort Brown, deltaic Waterford Formations and fluvial deposits of the Beaufort Group complete the succession (see Fig. 2 for detail). The Laingsburg Formation is further subdivided into basal Fan A, a basin-floor fan system (Sixsmith et al. 2004) overlain by Units B-F. Each unit represents a period of sandstone deposition in a mud-dominated, progradational system spanning basin-floor to upper-slope environments (Grecula et al. 2003). The deep-water succession has a maximum grain size of fine sandstone so - for the purpose of reservoir modelling - very-fine-grained sandstone and coarser is considered as net. Ongoing field-based research has shown that additional minor sandstone-prone units are present which are key to regional correlation: the A/B interfan between Fan A and Unit $\mathrm{B}$ and the $\mathrm{B} / \mathrm{C}$ interfan between Units $\mathrm{B}$ and $\mathrm{C}$ (Grecula et al. 2003), as well as a basin-wide, $30 \mathrm{~cm}$ thick marker bed called the Thin Siltstone Interval (TSI) within slope mudstones beneath Unit B (see Fig. 2 for detail). These units provide a robust lithostratigraphic framework that can be correlated across the Baviaans syncline.

The sedimentology of Unit B was first described by Grecula (2000), who divided it according to sedimentary architecture into a lower and generally thick-bedded unit and an upper thin-bedded and generally lower NTG unit. Subsequent work (Flint et al. 2010) divided Unit B into three depositional sequences: B.1, a generally thick-bedded high NTG interval overlain by a $2-4 \mathrm{~m}$ thick mudstone interval with regional extent; B.2, also a generally thick-bedded and high NTG interval; B.3, an upward-thinning and fining thin-bedded interval (the B.2 unit of Grecula 2000; see Fig. 2). The south-facing, sand-rich Skeiding outcrop is located near the nose of the Baviaans syncline and forms part of a ridge that can be traced for more than $15 \mathrm{~km}$ to the east and north around the syncline for a similar distance (Fig. 1b). Unit B in the Baviaans syncline has a thickness of approximately $225 \mathrm{~m}$ and is interpreted to represent a base-of-slope setting. The $1500 \mathrm{~m}$ wide Skeiding outcrop section exposes a channel complex set composed of three separate channel complexes and nine individual channels within sequences B.1 and B.2 (using the hierarchical description of submarine channel architecture defined by Sprague et al. 2002). The A/B interfan and/or the TSI units were used as 

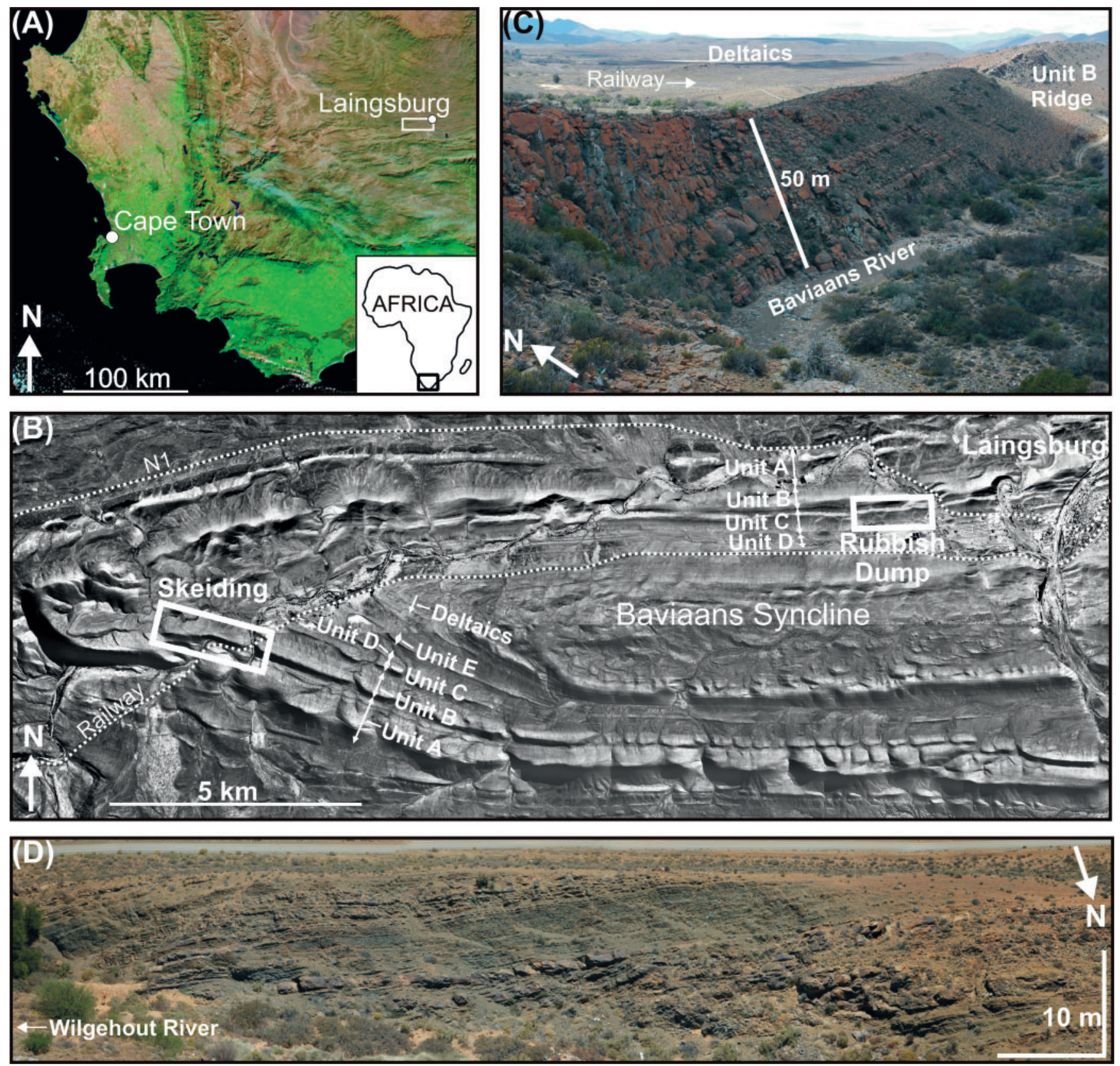

Fig. 1. (a) Landsat image of the Western Cape region with the study area marked. (b) Local ortho-rectified image of the Baviaans syncline with annotated study sites (boxes), railway and main road (N1) marked. Individual stratigraphic units (marked) of the Laingsburg Formation are visible as a series of ridges that trace the syncline. (c), (d) Outcrop photographs of the Skeiding and Rubbish Dump study sites, respectively. The aerial photograph is reproduced with the permission of the Chief Directorate; surveys and mapping South Africa.

datum units for assembling the Skeiding correlation panel. Some 3D control is provided by the Baviaans River which has shaped the Skeiding outcrop (Fig. 1c), with the local structural dip being $35^{\circ} \mathrm{NNE}$.

Unit B is overlain by a $60 \mathrm{~m}$ thick, regional hemipelagic mudstone, above which is a thin sandstone called the B/C interfan, then $20+\mathrm{m}$ of further hemipelagic mudstone, followed by the $60-100 \mathrm{~m}$ thick Unit C. Detailed mapping has allowed its subdivision into three sub-units (C.1, C.2 and C.3) separated by two hemipelagic mudstone units that are traceable for over $400 \mathrm{~km}^{2}$ (Fig. 2). Each sub-unit shows variations in thickness and not all the three units are present in all localities. The most proximal preserved part of Unit $C$, the ' $C$ axis', is located on the southern limb of the Baviaans syncline and is characterized by a number of stacked C.2-aged channel com- plexes confined by adjacent levees. The downdip continuation of the C.2 axis is a more divergent system featuring five isolated channel complexes exposed over a lateral distance of $16 \mathrm{~km}$ along the northern limb of the Baviaans syncline. The northfacing Rubbish Dump outcrop is located $10 \mathrm{~km}$ to the ENE and downdip of the $\mathrm{C}$ axis and provides a $720 \mathrm{~m}$ wide section through a sand-poor portion of one of these channel complexes. Exposure at the Rubbish Dump is excellent, particularly at the eastern end where quarrying has cleaned the outcrop face (Fig. 1d). The Rubbish Dump stratigraphy comprises units C.2 (dominated by a channel complex) and C.3 (thin beds). Mapping shows that C.1 pinches out a few kilometres to the west of the Rubbish Dump, and the mudstone separating C.1 from C.2 merges with the mudstone unit underlying Unit C. The regional $\mathrm{B} / \mathrm{C}$ interfan is also absent here. 


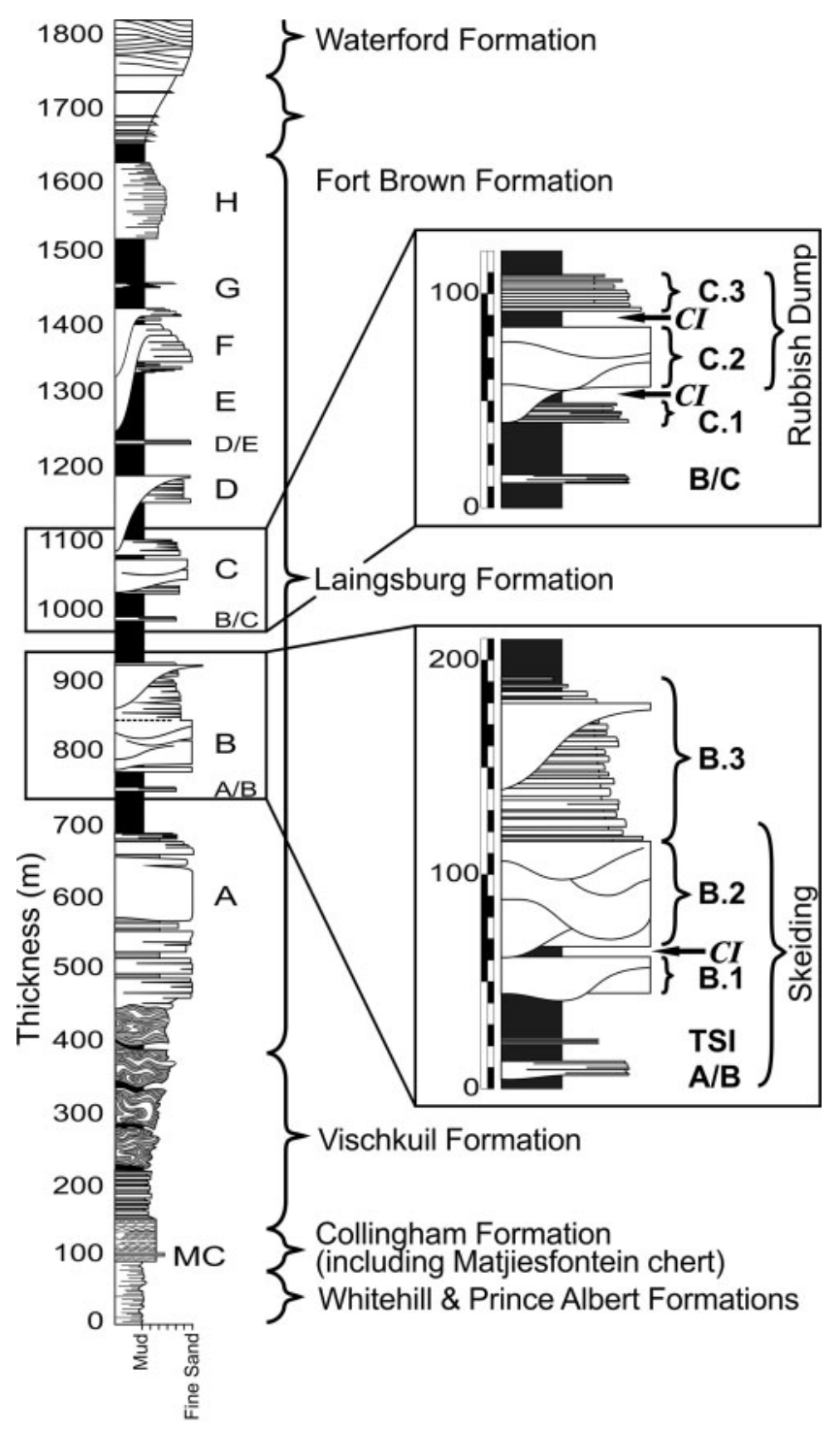

Fig. 2. Schematic lithostratigraphy of the early Laingsburg Karoo sediments. The Skeiding and Rubbish Dump channel complexes locations are marked. Sequential letters indicate correlatable sandrich units, modified from Figueiredo et al. (2010). The A/B and B/C Interfans, Intra-C mudstones $(C I)$ and the Thin Siltstone Interval (TSI) shown proved to be valuable aids to correlation.

Three-dimensional control is poor and the local structural dip is $45^{\circ}$ to the south.

\section{DATA ACQUISITION \& PROCESSING}

A range of methodologies and technologies were utilized at both the Skeiding and Rubbish Dump outcrops to extract the maximum amount of quantitative data and to integrate the data into a single spatially accurate digital dataset. The data were then interrogated and used for a variety of applications. The techniques, methodology, resulting data type(s) and their perceived usefulness in this study are summarized in Table 1.

\section{Conventional sedimentology}

A 16-fold lithofacies scheme was initially created from field reconnaissance of the Baviaans syncline (Fig. 3 and Table 2) and applied to subsequent field data. At each of the study localities closely spaced sedimentary logs (spaced $20 \mathrm{~m}$ apart at
Skeiding and $10 \mathrm{~m}$ apart at the Rubbish Dump) were simultaneously logged by a team at a resolution of $1 \mathrm{~cm}$. All erosion surfaces and a large proportion of individual beds to $<5 \mathrm{~cm}$ in thickness were walked out across the outcrop. The TSI unit, where present, was used as a datum horizon for the Skeiding correlation panel and corrected for post-depositional structural deformation (Fig. 4c). Over a distance of $1330 \mathrm{~m}, 61 \mathrm{logs}$ were measured, with a further two logs measured off-axis $\sim 1 \mathrm{~km}$ to the west for comparative purposes (Fig. 4a-c). At Laingsburg Rubbish Dump, 63 sedimentary logs were acquired over the $720 \mathrm{~m}$ wide outcrop (Fig. 5a-b). As the underlying B/C interfan was not present, the regionally extensive Upper $C$ shale (between C2 and C3) was used as a datum to produce the correlation panel (Fig. 5b).

\section{Digital aerial photogrammetry}

Twenty-six 9 inch aerial photographs at 1: 50000 scale of the area around Laingsburg were scanned at $7 \mu \mathrm{m}$ resolution and orthorectified within Leica Photogrammetry Suite ${ }^{\mathrm{TM}}$ software using dGPS surveyed ground control points that were visible on the photographs (Sgavetti 1992). The semi-automated procedure also produced as output a high resolution $(2 \mathrm{~m}$ grid $)$ digital elevation model (DEM), representing the modern ground topography. The DEM was then draped with a photomosaic assembled from the planimetrically correct (free of topographic and lens distortion) orthorectified aerial photographs (Fig. 1b). The DEM was also imported into Schlumberger Petrel ${ }^{\mathrm{TM}}$ software as ASCII x, y, z points and a digital, minimum curvature-gridded surface was created and draped with the orthorectified images to provide a topographic framework for the integration of subsequent field datasets (Fig. 6).

\section{Outcrop and helicopter-derived photomosaics and interpretations}

Digital outcrop photographs were taken and combined into photomosaics for interpretative processes (Figs $4 \mathrm{a}$ and $5 \mathrm{a}$ ). The effect of topographic foreshortening was reduced by obtaining sequentially-taken photographs from both ground level and the helicopter at fixed distances to create photomosaics (Figs $4 \mathrm{~b}$ and 5b; see Arnot et al. 1997 for technique background and methodology).

\section{Digitized sedimentology}

Digitization of the sedimentary $\operatorname{logs}$ was conducted using VRGS ${ }^{\mathrm{TM}}$ digital logging software (Fig. $7 \mathrm{a}-\mathrm{b}$ ) and the 16 lithofacies types were also grouped into lithofacies associations, based on respective lithofacies distributions and field observations (Fig. 3; Table 2). Lithofacies association information was important as lithofacies interpreted to have been deposited in differing sedimentary environments (e.g. internal levee versus overbank) typically have similar reservoir properties. VRGS format sedimentary logs also allowed semi-automated quantification and analysis of individual log lithofacies and lithofacies association proportions (Fig. $7 \mathrm{~d}$ ), together with log average grain size and user-specified NTG ratio statistics to be generated (Figs 4c-e and 5d-f) and even average lithofacies association bed thickness statistics (Fig. 7f). Converting conventional outcrop data to more typical reservoir unit information is useful to reservoir engineers when comparing these outcrops to producing reservoirs. Digitizing sedimentary logs was also a necessary step to generate synthetic log data. 


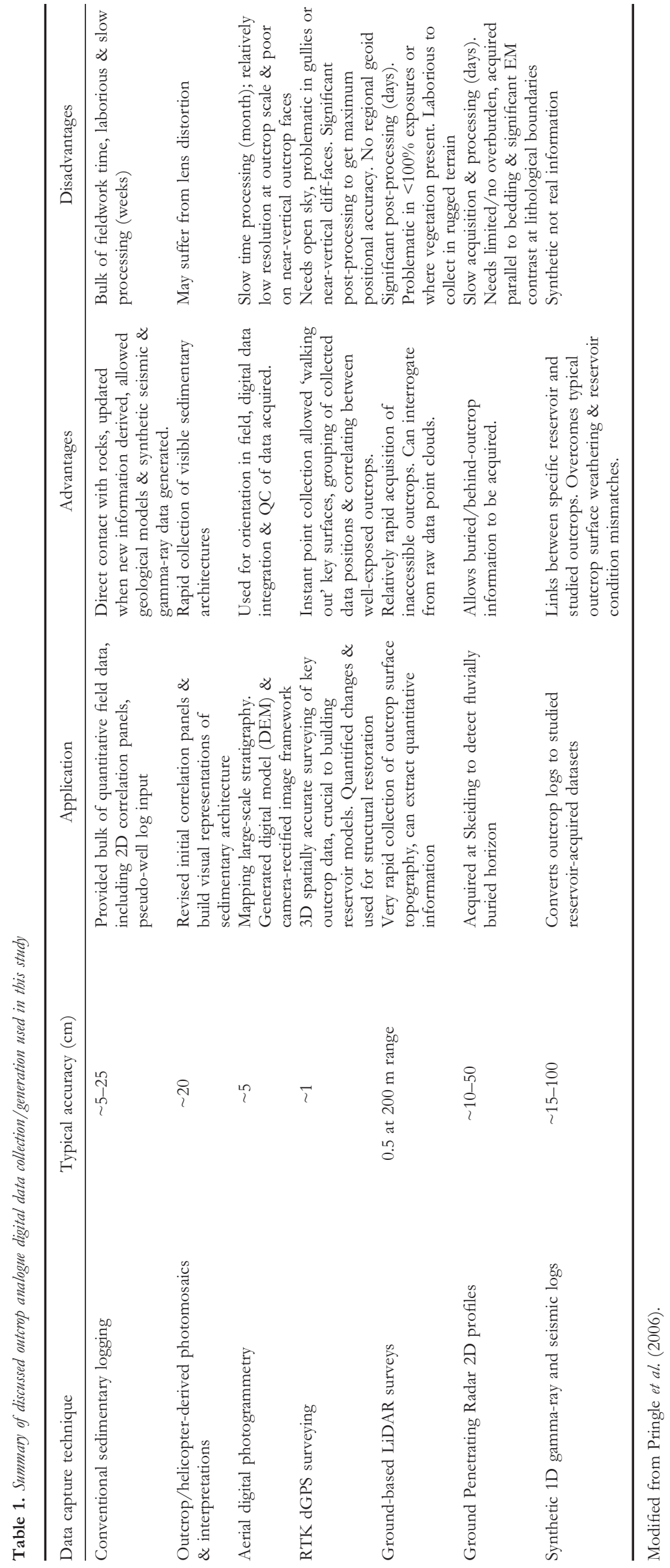



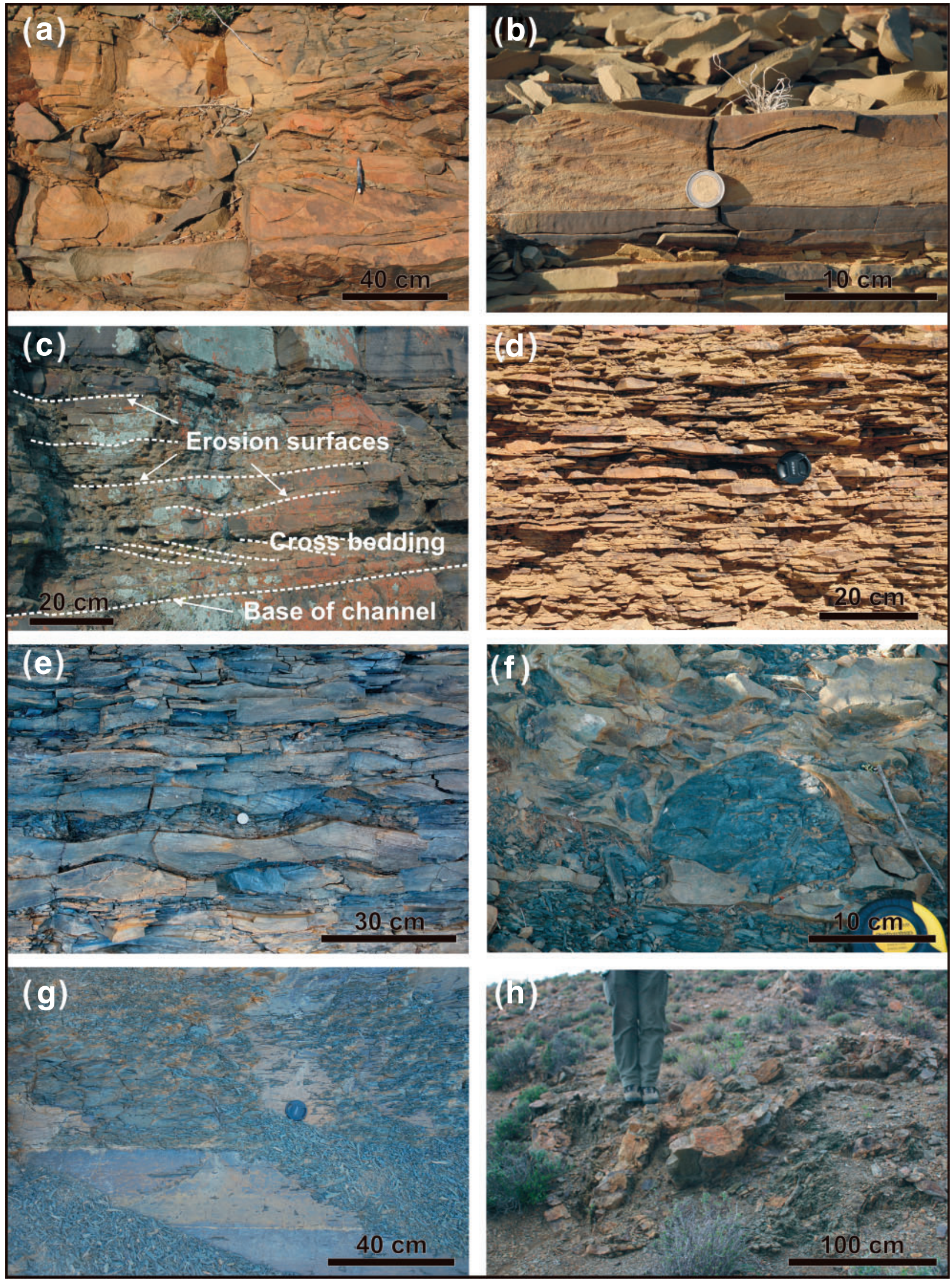

Fig. 3. Representative lithofacies photographs with scale bars: (a) amalgamated, typically structureless, sandstones; (b) structured sandstones, with climbing ripple lamination; (c) thin-bedded, planar-laminated fine sandstones with low-angle erosional surfaces (annotated); (d) thin-bedded, ripple-laminated fine sandstones; (e) thin-bedded heteroliths, comprising sandstone, siltstone and occasional shale intervals; (f) mudstone clast-supported conglomerate commonly found in axial channel bases; (g) claystone (Unit B.1 mudstone interval); (h) slump, commonly found on channel margins. Lithofacies modified from Grecula et al. (2003). 


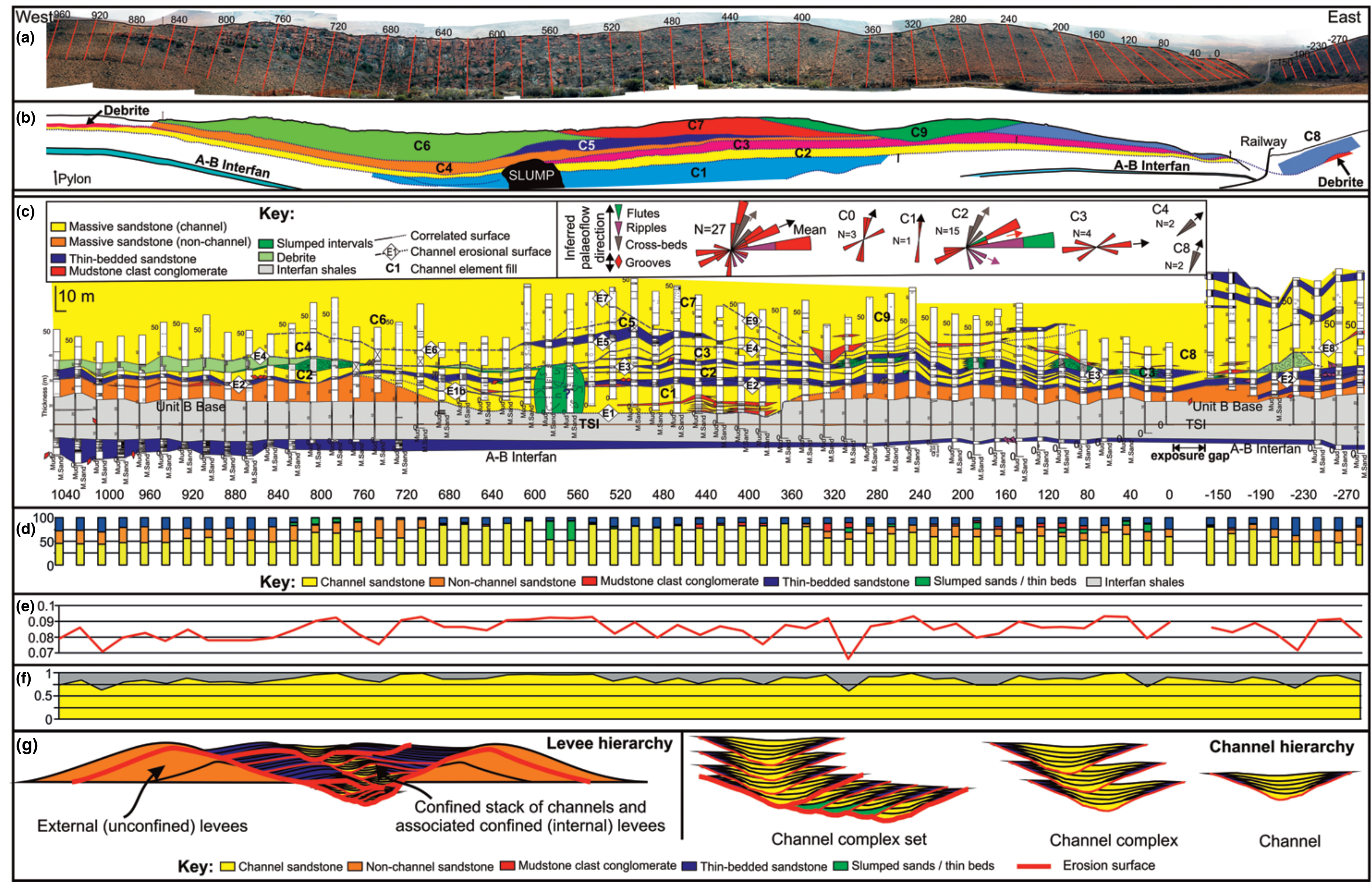

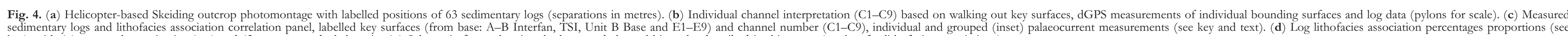

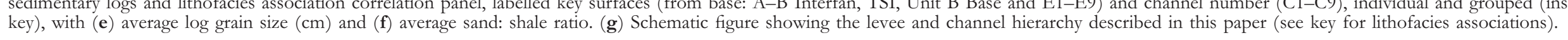




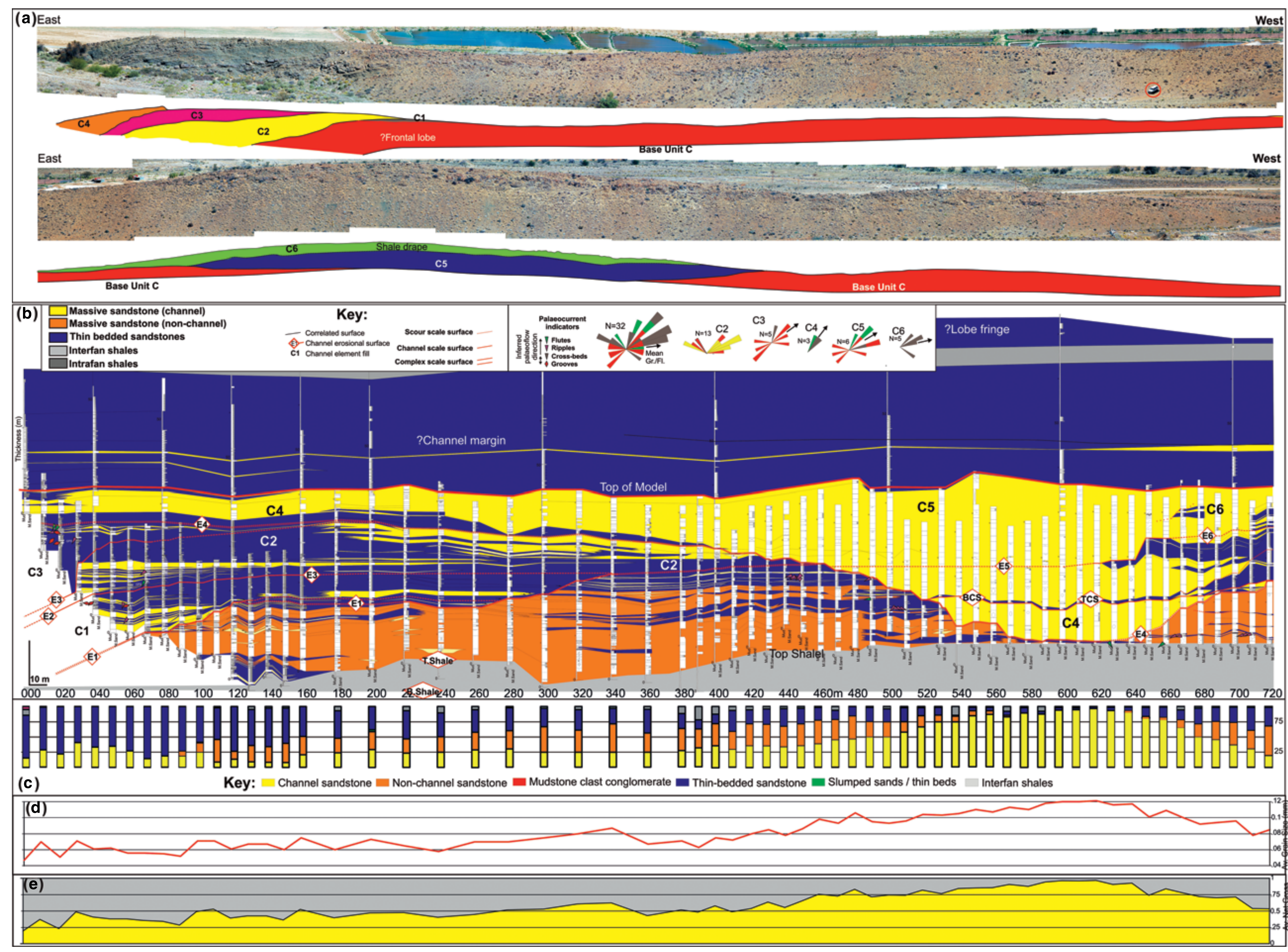

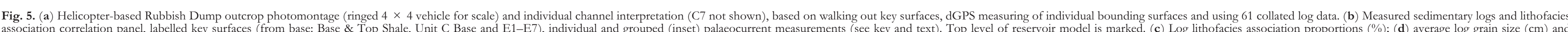
(e) average sand: shale ratios of modelled section 


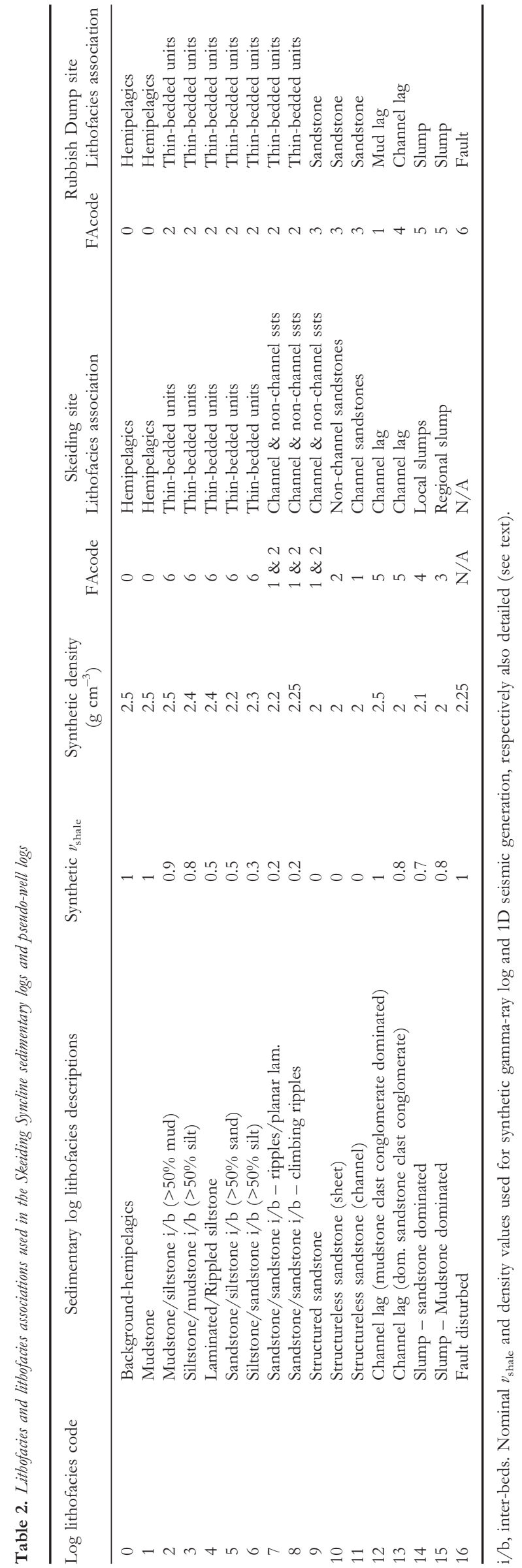

\section{Synthetic gamma-ray and seismic logs}

The digitized sedimentary logs were imported into Petrel ${ }^{\mathrm{TM}}$ software as pseudo-well logs which were assigned additional information including: $\mathrm{x}, \mathrm{y}, \mathrm{z}$ position (using the dGPS survey information); grain size; bed count; lithofacies; lithofacies association and NTG at a user-specified unit. The Petrel pseudo-well logs were then manipulated and resampled using a spreadsheet application (Clark, pers. comm. 2007) into more realistic synthetic gamma-ray log values, using typical oil-field $v_{\text {shale }}$ values for each lithofacies (see Table 2 and Gluyas \& Swarbrick 2004), a $0.15 \mathrm{~m}$ sampling increment, logarithmicdeclining attenuation and a $4 \mathrm{~m}$ search radii (examples in Fig. 7c). Generating pseudo-gamma-ray logs directly from outcrop data avoids the comparison problems usually associated with outcrop surface weathering and different pressure/ temperatures that effect field probe permeameter and radioactivity field measurements when compared to reservoir measurements (see Jones et al. 1984; Arnot et al. 1997).

Forward modelling of 1D seismic (Ricker) wavelets from the pseudo-well logs at user-specified dominant frequencies allowed direct comparison of reservoir seismic datasets with outcrop data (Fig. 7e; also see Pringle et al. (2004) for more information). The 1D forward seismic models were generated by digitally assigning typical densities to each lithofacies association (Table 2), then successively generating synthetic sonic, acoustic impedance and reflection coefficient logs. Ricker wavelets at $30 \mathrm{~Hz}, 50 \mathrm{~Hz}$ and $100 \mathrm{~Hz}$ dominant frequency were chosen to be generated for each log, representing the typical frequencies and resolutions associated with reservoir seismic datasets. These synthetics were relatively simple to generate but it should be noted that densities measured at reservoir conditions should be used instead of the values used in this example.

\section{Ground-based RTK dGPS surveying}

Detailed surveying using Real-Time Kinematic (RTK) dGPS Trimble 5800 equipment (see Pringle et al. 2006 for dGPS methodology background) was used to accurately $(\sim 1 \mathrm{~cm})$ measure a variety of data types. For instance, traditional field measurements, such as point locations of structural dip and palaeocurrent data, were accurately placed in a 3D framework along with the base and top position of each logged section. The outcrop shapes of key stratigraphic surfaces, architectural bounding surfaces and erosional surfaces were also surveyed while 'walking out' in the field (Fig. 6). This built up a database of both detailed outcrop-scale sedimentary architecture and regional-scale correlations over the course of the project. This quantitative survey approach allowed both the accurate placement of key outcrop measurements (Fig. 6), the subsequent digital restoration to horizontal of key surfaces and their associated statistics and grouping of palaeocurrent positions between key stratigraphic surfaces to be achieved (Table 3). Palaeocurrent measurements (Figs 4, 5) were also adjusted $\left(-19^{\circ}\right.$ to $+5^{\circ}$ range $)$ to account for post-depositional tilting of the strata.

\section{Ground-based LiDAR surveys}

Ground-based Light Detection and Ranging (LiDAR) surveys have been shown to acquire xyz coordinate data point clouds rapidly and accurately (up to 12000 points per second and at less than $5 \mathrm{~mm}$ xyz data-point spacing under optimal data collection conditions) from a scan position of up to $1 \mathrm{~km}$ from the outcrop (Pringle et al. 2006). A digital camera, mounted on top of LiDAR data-collection instruments, photograph the 
survey area and add RGB (red, green and blue) values to each of the data points to produce almost photo-realistic data-point clouds. Resulting datasets can then be used to extract relatively large-scale stratigraphic architecture (e.g. Bellian et al. 2005; Fabuel-Perez et al. 2010) or for analysis of small-scale outcrop fault and fracture distribution studies (e.g. Clegg et al. 2005; Jones et al. 2009).

Multiple scans from different orientations using a Riegl LMS-Z420i ${ }^{\mathrm{TM}}$ tripod-mounted instrument were needed to obtain full outcrop coverage of the rugose surface, acquiring 29.3 million data points (Skeiding, 8 scan positions and 25.1 million data points; Rubbish Dump, 5 scan positions and 29.3 million data points). The data-point clouds at each site were merged and processed into real-world (UTM) coordinates using Riegl LMS-Z RI-Scan Pro ${ }^{\mathrm{TM}}$ software. This was possible as both the scan tie points (usually $5+$ reflective markers placed around the scanner) and the scan position itself were dGPS surveyed. The resulting data-point clouds were then rotated to view along depositional dip, removing foreshortening effects (Fig. 8). Three-dimensional poly-lines, representing sedimentary geometries and bed width and thickness measurements, were also extracted (Fig. 8b) and imported into the Petrel ${ }^{\mathrm{TM}}$ dataset. This was especially important in the channel-axis area at Skeiding, where the near-vertical cliff faces prevented both sedimentary logging and dGPS surveying. Results were then integrated with the logging and surveying datasets.

\section{Ground Penetrating Radar (GPR) surveys}

The erosive base of the Skeiding channel complex set (surface E1) incises into underlying slope mudstones, but this relationship is buried beneath the modern Baviaans river sediments. A short GPR survey was undertaken to image this horizon and quantify the erosional depth and extent. Sensors \& Software PulseEKKO ${ }^{\mathrm{TM}} 1000$ GPR equipment was used to acquire multiple $1 \mathrm{~m}$ fixed-offset 2D profiles using $100 \mathrm{MHz}$ dominant frequency antennae. Trace samples were acquired at $0.2 \mathrm{~m}$ spacing along survey lines with 300 ns Time Window and 32 repeat stacks on each trace position. Two-dimensional profiles were acquired directly upon bedding surfaces to negate the effects of any post-depositional tilting (Fig. 9). The survey imaged the base of the Skeiding channel complex set. Acquiring successive $2 \mathrm{D}$ profiles at increasing distances from the outcrop enabled the orientation of this surface to be established later in 3D. Profiles were also dGPS surveyed to aid in integration into the digital Petrel ${ }^{\mathrm{TM}}$ model.

Standard GPR profile image optimization processing steps (see Pringle et al. 2003 for background) of first-break arrival and time-zero corrections, a manual gain filter, topographic surface correction (using the dGPS survey information) and an average site velocity of $0.092 \mathrm{~m} \mathrm{~ns}^{-1}$ used to convert profiles to depth (obtained from a common mid-point (CMP) survey) was undertaken using Sandmeier Scientific REFLEX-W ${ }^{\mathrm{TM}}$ software. The resulting processed profiles were output as standard seismic (SEG-Y) format and imported into the Petrel ${ }^{\mathrm{TM}}$ model dataset.

\section{Digital outcrop model and digital data analysis}

All the remote and field data already described (Table 1) were integrated into a single Petrel ${ }^{\mathrm{TM}}$ model in their true, UTM coordinate spatial positions (Fig. 6). dGPS survey data were imported as ASCII points with attributes, including positional information, Identification Tag (ID), stratigraphic location, any directional information and confidence rating. A unique point ID and confidence rating allowed points to be compared within the integrated dataset. Thus, suspect points with low confidence ratings could be removed if they conflicted with neighbouring point positions. After this checking procedure was completed, 3D poly-lines of all the key stratigraphic horizons could be created (see Fig. 6). Poly-line position and associated dip data could then be used to calculate thickness changes over significant $(5 \mathrm{~km}+)$ distances of entire stratigraphic units or erosionally bounded architectural elements, such as channels. The state of surface completeness (complete, partial or unlimited, following Geehan \& Underwood (1993) methodology) and $2 \mathrm{D}$ bed width/thicknesses relationships could also be extracted (Table 3). The widths of key surfaces needed to be adjusted for both outcrop rugosity (step 1) and outcrop obliquity (step 2). This was comparatively straightforward as all the logs and their associated surface positions were dGPS surveyed (Fig. 10a/b). Step 1 involved a simple comparison between the $2 \mathrm{D}$ correlation panel width and the true $3 \mathrm{D}$ coordinate positions; step 2 involved calculating a true, or perpendicular to palaeoflow channel width based on the assumption that channel trajectory is reflected in the orientation of the structurally restored groove and flute-derived palaeocurrent values measured within the fill of each channel (Table 3; Fig. 10c). Palaeocurrent measurements derived from ripple cross-lamination were given less emphasis, as they are deposited by weaker flows and are therefore more likely to deviate from the true channel trend. The $2 \mathrm{D}$ correlation panels were also analysed for lithofacies association, measured bed width and thickness data. The individual bed width data also needed to be adjusted for outcrop rugosity and their respective mean palaeoflow direction, depending upon their position within the outcrop (see Figs 4, 5) using the method already described. The resulting lithofacies association datasets (shown as combined histogram plots in Fig. 11) could then be used as input for stochastic reservoir modelling.

\section{SEDIMENTOLOGY AND STRATIGRAPHY}

\section{Skeiding outcrop (Unit B)}

The outcrop consists of nine channel-fills (C1-C9) organized into three channel complexes (Complexes A, B and C) based on channel geometries, stacking patterns and the presence of a regionally extensive hemipelagic mudstone between complexes $A$ and B (Fig. 4). Underlying the channels is a basal amalgamated fine-grained sandstone ( $6 \mathrm{~m}$ thick) which thins and becomes more stratified laterally over approximately $2 \mathrm{~km}$, and is interpreted as a (frontal) lobe. Channel C1 of Complex A incises into the centre and thickest part of the lobe to a depth of $13 \mathrm{~m}$ (from GPR) and has a width of $300 \mathrm{~m}$. The fill of C1 consists mainly of amalgamated sandstones, but contains thick horizons of mudstone clast conglomerates that are interpreted to indicate extensive updip erosion and sediment bypass to the deeper basin. Channel C2, the other channel-fill in Complex A, stacks vertically on top of $\mathrm{C} 1$ and is high aspect ratio (45: 1) and characterized by sand-prone channel wings that extend the full width of the studied outcrop. Overlying Complex A is a $4 \mathrm{~m}$ thick mudstone unit that locally contains chaotic assemblages of siltstone and sandstone clasts. The unit is correlated with an intra-B mudstone that can be identified over much of the Laingsburg area.

Above the mudstone, Complex B channels (C3, C4 and C5) are high aspect ratio ( 40: 1$)$ and also show the development of extensive channel wings. The axis of each channel-fill incises to a maximum depth of $9 \mathrm{~m}$ with a sub-vertical stacking pattern. The gradient of the incisional bounding surface varies from $5^{\circ}$ in axial areas to $1^{\circ}$ beneath the channel wings. The infill 


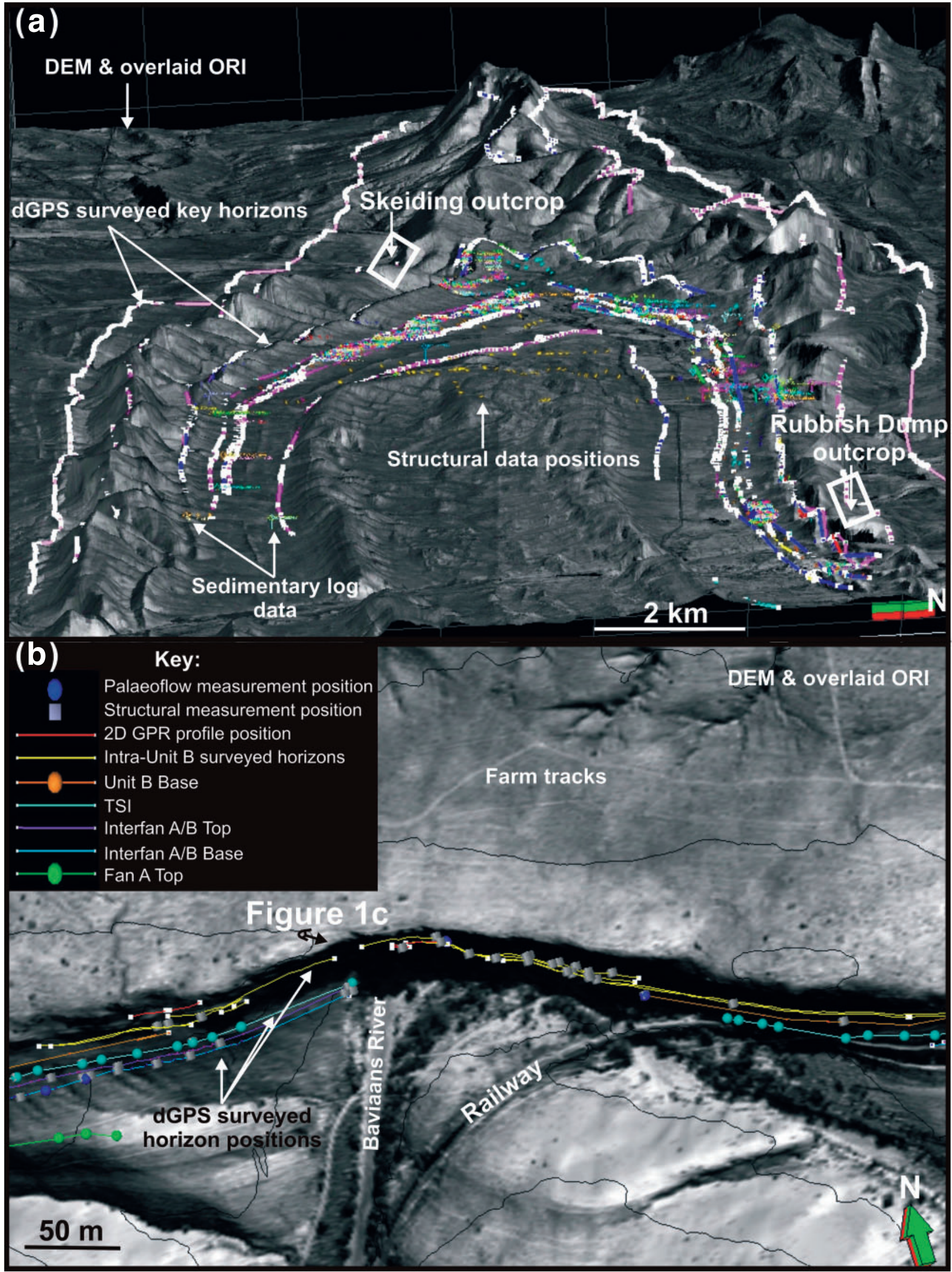

Fig. 6. (a) Digitally integrated, outcrop-derived datasets in Schlumberger Petrel ${ }^{\mathrm{TM}}$ visualization software. The digital aerial photogrammetric DEM and draped ortho-rectified image (ORI) output, dGPS mapped positions of key stratigraphic horizons, internal bed architecture, structural and palaeocurrent data sampling points, sedimentary well logs and 2D GPR profiles are marked. Location of (b) shown as white square, Skeiding outcrop. (b) Integrated dataset close-up at the Skeiding outcrop with key (inset). Aerial photographs reproduced with the permission of the chief Directorate: Surveys and mapping (South Africa). 
(a) (b)

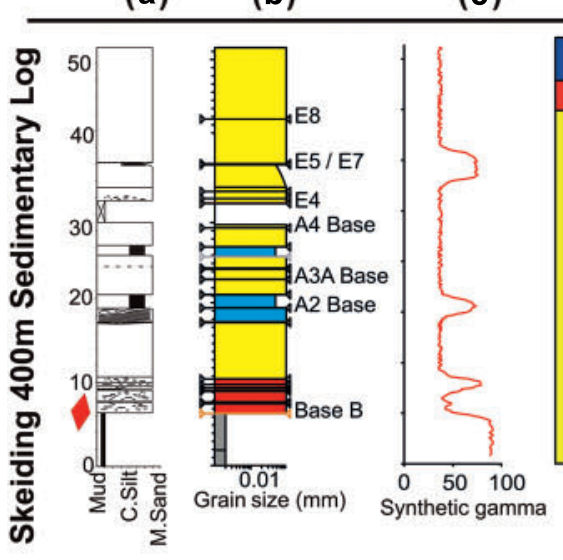

(d)

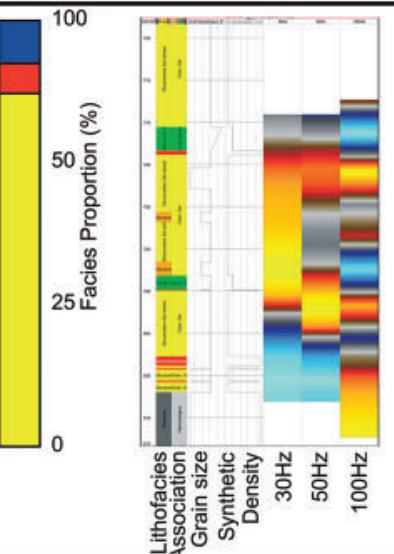

(f)

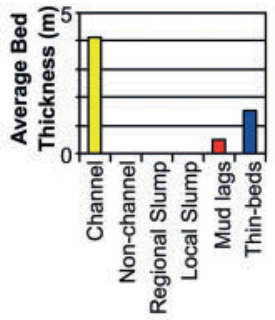

Facies Association
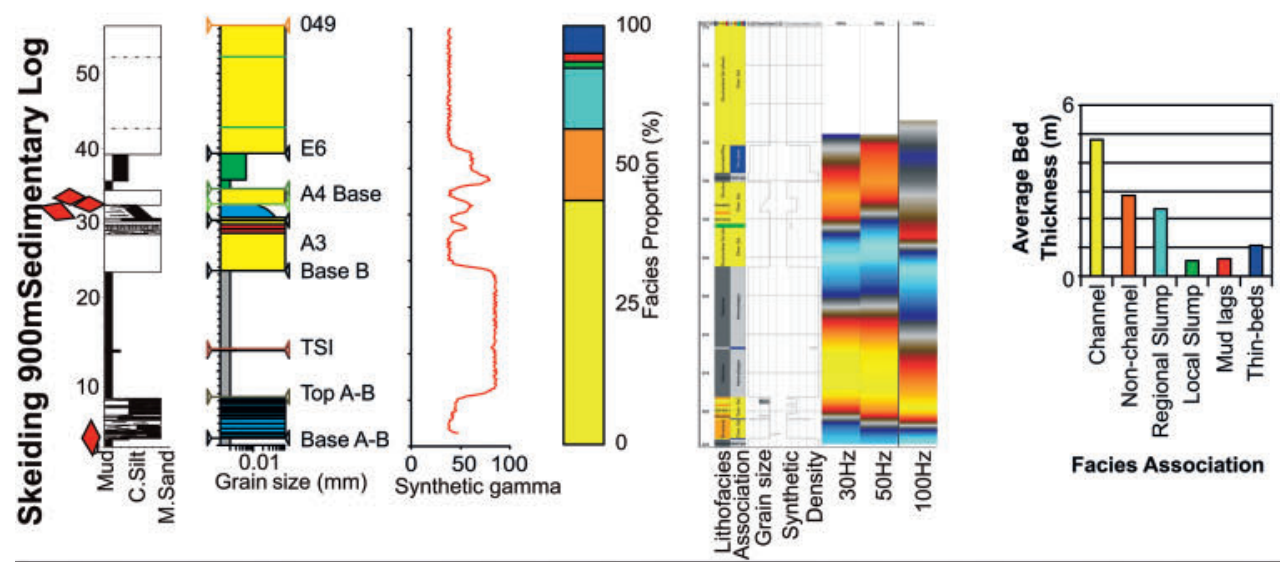

Facies Association
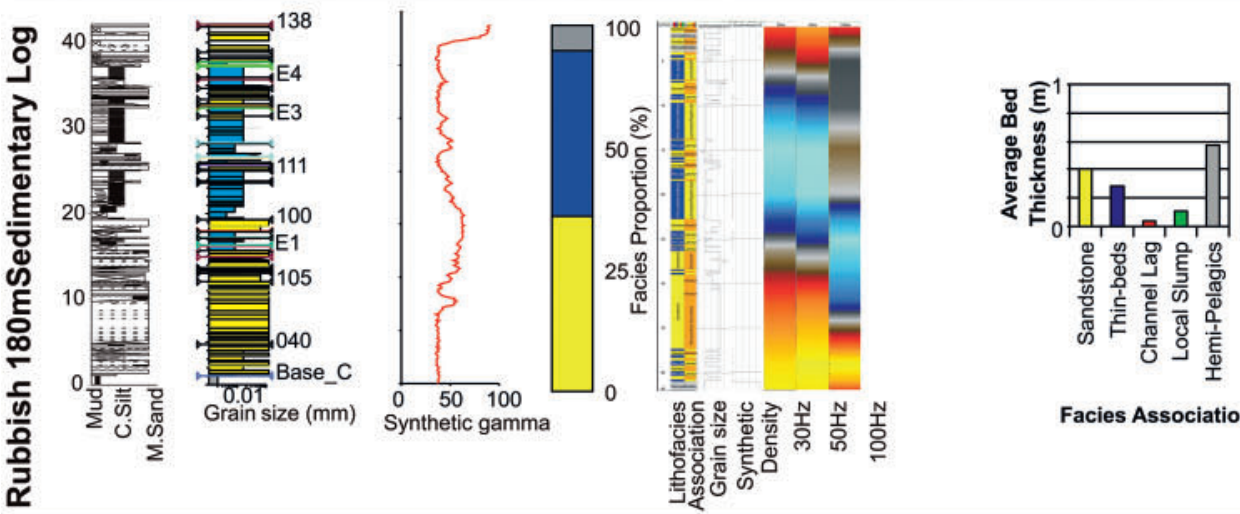

Facies Association

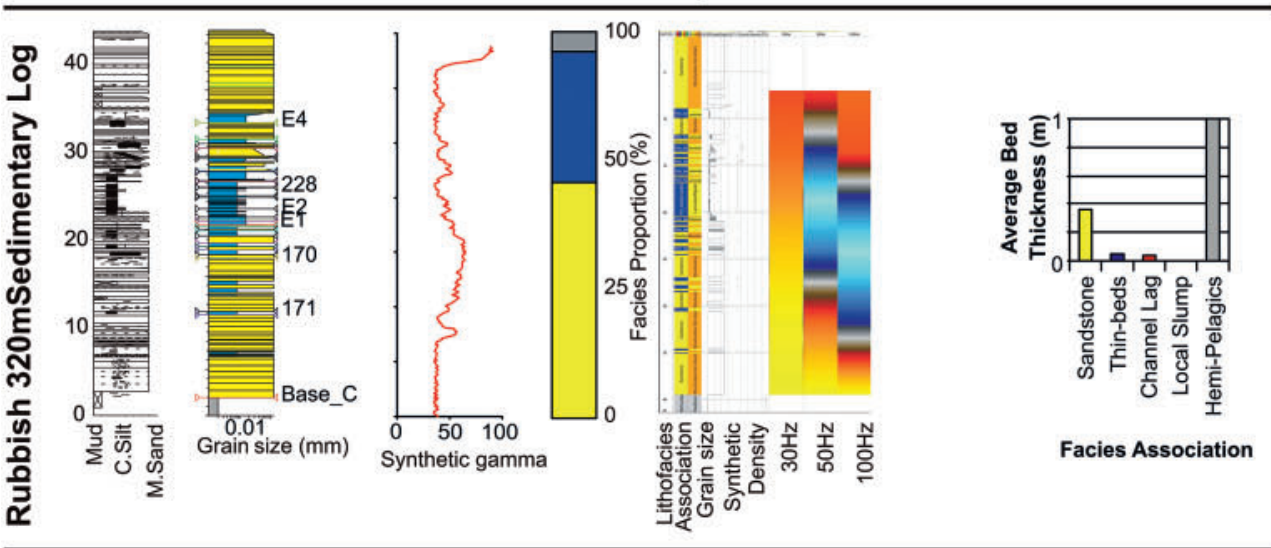

Fig. 7. (a) Examples of digitized outcrop sedimentary logs; (b) digital log versions with correlated stratigraphic surfaces marked; (c) respective lithofacies association log proportions; (d) synthetic 1D gamma-ray logs (see text); (e) synthetic 1D $30 \mathrm{~Hz}, 50 \mathrm{~Hz}$ and $100 \mathrm{~Hz}$ seismic generated from outcrop logs (see text); and (f) respective average lithofacies association bed thicknesses. Colour codes are the same as Figures 4 (Skeiding) and 5 (Rubbish Dump), respectively. 
Table 3. Skeiding and Rubbish dump outcrop key surface statistics

\begin{tabular}{|c|c|c|c|c|c|c|c|}
\hline Outcrop site & $\begin{array}{l}\text { Key stratigraphic } \\
\text { surface }\end{array}$ & Surface type & $\begin{array}{l}\text { Vertical variation } \\
\text { across outcrop } \\
(\mathrm{m})\end{array}$ & $\begin{array}{l}2 \mathrm{D} \text { photopanel } \\
\text { width }(\mathrm{m})\end{array}$ & $\begin{array}{l}\text { Width corrected } \\
\text { for outcrop } \\
\text { rugosity }{ }^{*}(\mathrm{~m})\end{array}$ & $\begin{array}{l}\text { Inferred palaeo- } \\
\text { flow direction } \\
\quad\left(^{\circ}\right) \& \text { (no.) }\end{array}$ & $\begin{array}{l}\text { Corrected width } \\
\text { perpendicular to } \\
\text { palaeoflow }^{\dagger}(\mathrm{m})\end{array}$ \\
\hline Skeiding & E8 & Partial & 31.90 & 710 & 655 & $45(2)$ & 118.25 \\
\hline Skeiding & E7 & Partial & 21.82 & 200 & 203 & $10(1)$ & 147.03 \\
\hline Skeiding & E6 & Partial & 11.20 & 330 & 305 & $10(0)$ & 248.01 \\
\hline Skeiding & E5 & Complete & 4.63 & 190 & 187 & $45(0)$ & 22.61 \\
\hline Skeiding & $\mathrm{E} 4$ & Partial & 9.43 & 710 & 680 & $30(2)$ & 312.35 \\
\hline Skeiding & $\mathrm{E} 2$ & Unlimited & 15.60 & 1330 & 820 & $77.8(15)$ & $\mathrm{N} / \mathrm{A}$ \\
\hline Skeiding & E1c & Complete & 4.00 & 140 & 132.5 & $10(0)$ & 105.44 \\
\hline Skeiding & E1b & Complete & 16.30 & 360 & 340 & $15(0)$ & 236.13 \\
\hline Skeiding & E1 & Complete & 16.60 & 440 & 417 & $9(1)$ & 336.33 \\
\hline Skeiding & Base B & Unlimited & 8.60 & 1330 & 820 & $32(3)$ & $\mathrm{N} / \mathrm{A}$ \\
\hline Skeiding & TSI & Unlimited & 0.00 & 1330 & 820 & $\mathrm{~N} / \mathrm{A}$ & $\mathrm{N} / \mathrm{A}$ \\
\hline Skeiding & A/B Top & Unlimited & 8.58 & 1330 & 820 & $66(7)$ & $\mathrm{N} / \mathrm{A}$ \\
\hline Rubbish Dump & E6 & Complete & 4.50 & 30 & 30 & $83(5)$ & 13.5 \\
\hline Rubbish Dump & TCS & Partial & 12.90 & 200 & 200 & $\mathrm{~N} / \mathrm{A}$ & $\mathrm{N} / \mathrm{A}$ \\
\hline Rubbish Dump & BCS & Partial & 6.50 & 200 & 200 & $\mathrm{~N} / \mathrm{A}$ & $\mathrm{N} / \mathrm{A}$ \\
\hline Rubbish Dump & $\mathrm{E} 4$ & Unlimited & 27.25 & 720 & 712 & $76.2(3)$ & 233.1 \\
\hline Rubbish Dump & E3 & Partial & 19.50 & 220 & 212 & $38(5)$ & 70.6 \\
\hline Rubbish Dump & $\mathrm{E} 2$ & Partial & 14.25 & 460 & 444 & $54.8(5)$ & 17.74 \\
\hline Rubbish Dump & E1 & Complete & 28.00 & 340 & 326 & $63.8(13)$ & 38.3 \\
\hline Rubbish Dump & Top shale & Unlimited & 10.25 & 720 & 712 & $\mathrm{~N} / \mathrm{A}$ & $\mathrm{N} / \mathrm{A}$ \\
\hline Rubbish Dump & Base shale & Unlimited & 10.95 & 720 & 712 & $\mathrm{~N} / \mathrm{A}$ & $\mathrm{N} / \mathrm{A}$ \\
\hline
\end{tabular}

${ }^{*}$ Corrected for outcrop rugosity (using dGPS survey information).

tValues from asterisked column rotated using simple trigonometry to become perpendicular to mean palaeoflow directions.

Logs corrected to the TSI reference surface for Skeiding. Complete observed surface widths have both ends terminated, partials have 1 termination and unlimited have no terminations (following Geehan \& Underwood 1993). Inferred palaeoflow direction based on measured indicators (total) and/or best-guess. Measured grooves/flutes were given greater bias than ripple/cross-bed values. Best-guess measurements based on channel bases, surface orientations and facies distribution assymmetries.

of Complex B channels is predominantly amalgamated sandstones in the axial region and shows a gradual lithofacies transition to rippled thin-bedded sandstones in off-axis areas. Scour-based thin-bedded sandstones' onlap basal erosion surfaces mantled with mudstone chips are found in a number of the channel-fills and interpreted as deposition from the finegrained tails of bypassing turbidity currents (Grecula et al. 2003). The total thickness of Complex B deposits at Skeiding is $25 \mathrm{~m}$.

Complex C channels (C6-C9) show a switch to a more erosional regime, incising up to $26 \mathrm{~m}$ into Complex $\mathrm{B}$. The component channels of Complex $\mathrm{C}$ are also narrower, with a typical aspect ratio of $\sim 10: 1$ and, in contrast to Complexes $\mathrm{A}$ and B, stack laterally. Channels C6-C8 stack in an easterly direction and the final channel, C9, steps to the west, with each channel eroding down from a similar stratigraphic level (limited aggradation). Complex $\mathrm{C}$ channels are filled by amalgamated sandstone with little internal variation. The presence of little to no overbank deposits to Complex $\mathrm{C}$ suggests confinement of flow is entirely due to the erosional depth of the channel. Overlying the Skeiding channel complex set is $100 \mathrm{~m}$ of ripple-laminated thin-bedded sandstones and siltstones that make up B3. Beds are typically no thicker than $0.1 \mathrm{~m}$ and may represent an external levee to a B.3 channel system exposed to the east of Skeiding.

Although issues of data density and processing time limit detailed geological modelling of the Skeiding outcrop, direct correlation of Unit B sequences with downdip localities was conducted in the Laingsburg area. From this work the Unit B succession at Skeiding (Fig. 12a) is interpreted to reflect stepped progradation of a base-of-slope system. The initial phase of basinward movement is seen by the incision of C1 through a genetically related frontal lobe. Usable accommo- dation was sufficient throughout Complexes A and B to allow vertical stacking of component channels, whereas the deeper incision and lateral stacking within Complex $\mathrm{C}$ indicates less usable accommodation and perhaps a steeper gradient or increased confinement. Infill of the channels was rapid and in general did not allow for the development of facies heterogeneity. In contrast, early deposition in Complex A and B channels took place above a broad deflationary surface. Over time, flow was concentrated into the central region of the deflationary surface, forming the more deeply eroded axial region of the channel. Subsequent backstepping leads to infill of the channel and broader deflationary surface with structureless sandstones forming the amalgamated axial region and laterally extensive channel wings.

\section{Laingsburg Rubbish Dump outcrop (Unit C)}

At the Laingsburg Old Rubbish Dump outcrop two channel complexes were identified within sequence C.2 of Unit C and are termed the eastern and western complexes (Fig. 5). The western margins of four individual channel-fills are identified within the eastern complex, each with different architectural characteristics (Fig. 12b). Cross-cutting relationships indicate that each channel represents discrete cutting and filling episodes. Channels 1-4 are considered part of the same channel complex due to their consistent stacking pattern in which each channel-fill steps to the east with a slightly aggradational trajectory. The axes of channels 1-4 are not exposed. The younger western complex cuts the western margins of channels 1-4 and includes channels 5-7. Vertical stacking within the western complex provides a more complete record of acrosschannel facies distribution as both east and west margins of component channels are preserved. 

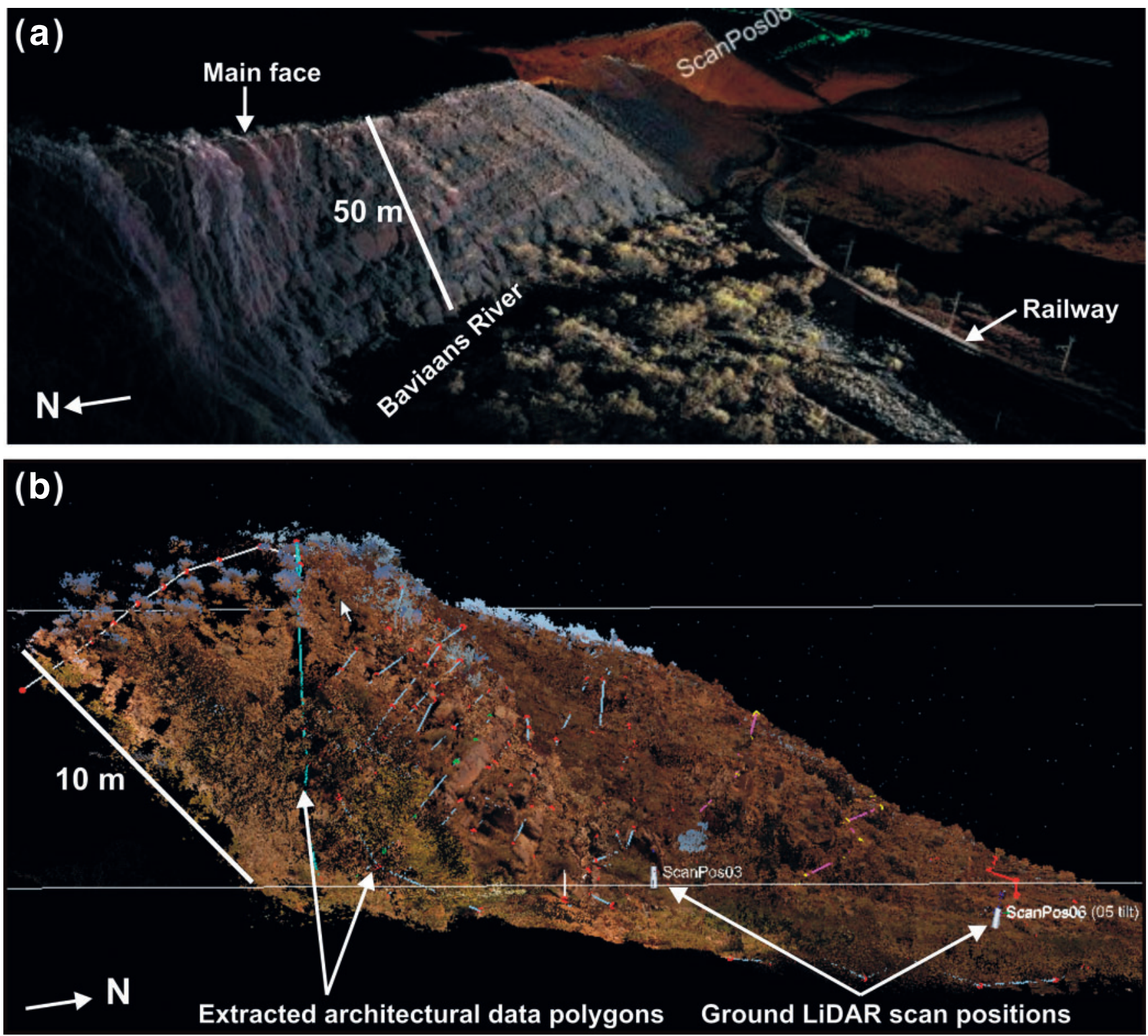

Fig. 8. Screen-shots of (a) Skeiding and (b) Rubbish Dump outcrop datasets obtained by a ground-based, Leica LMZ 720i LiDAR system. (a) 29.3 million LiDAR xyz data-point cloud merged from 8 scan positions and 19 swaths with scanned railway for scale. (b) 8.6 million LiDAR xyz data-point cloud merged from 7 scan positions, 15 swaths and showing interpreted sedimentary architecture poly-lines. Scan positions 3 and 6 are $10 \mathrm{~m}$ apart. Digital photographs acquired at scan positions allowed each data point to be RGB coloured, with dGPS information of each scan position then converting merged datasets to real-world (UTM) coordinates.

The base of Unit $\mathrm{C}$ at the Laingsburg Rubbish Dump is marked by $20 \mathrm{~m}$ of amalgamated fine-grained sandstone beds containing occasional thin contorted horizons a few metres in width and minor accumulations of mudstone clasts, particularly within the lowermost section. The basal high NTG unit fines and thins upward into thin-bedded sandstones and siltstones and also becomes less amalgamated and finer grained to both the east and west of the $720 \mathrm{~m}$ wide outcrop. The geometry, lithofacies and stratigraphic position of this unit lead to the interpretation that it is the amalgamated axial part of a frontal (or precursor) lobe deposited by decelerating turbidity currents downdip of a submarine channel.

Channel 1 consists of an easterly dipping remnant of the western margin of a larger channel which cuts downward at an outcrop angle of $\sim 4^{\circ}$ (assuming a NE channel orientation based on palaeocurrents) for $7.5 \mathrm{~m}$ before the incisional gradient decreases towards the interpreted axis of the channel
(Fig. 5b). The axial erosional surface remains close to bed parallel for $>100 \mathrm{~m}$ before being cut out by Channel 2 . The fill consists mainly of horizontally bedded planar-laminated siltstones and sandstone beds up to $1 \mathrm{~m}$ in thickness which onlap in a westerly direction onto the erosional channel margin.

Channel 2 steps laterally to the east of Channel 1 by $300 \mathrm{~m}$, eroding through part of the earlier fill as a function of the lateral stacking pattern (Fig. 5b). The erosional channel margin can be traced across the outcrop for more than $100 \mathrm{~m}$, dipping east at $11^{\circ}$ at its steepest (reconstruction based on NE directed palaeocurrents) where it is associated with minor slumping of initial fill. Lateral to the area of maximum incision, the gradient of the margin slowly decreases to a point where it ceases to truncate underlying beds and becomes parallel to them. This point is interpreted as transitional to overbank deposition (at the scale of the channel) and is associated with an off-axis transition to more sand-prone lithofacies (see Channel 2 


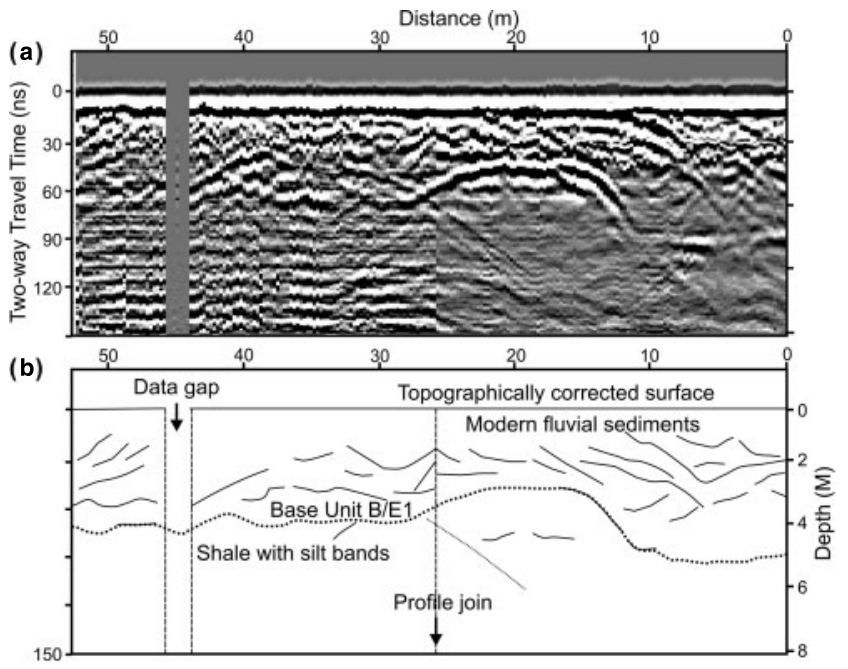

Fig. 9. (a) PulseEKKOTM Ground Penetrating Radar (GPR) 100 $\mathrm{MHz}$ dominant frequency 2D profile. (b) Annotated interpretation to image the Unit B/E1 key stratigraphic horizon at the Skeiding outcrop, which was buried by modern fluvial sediments.

interval between logs 140 and 200) interpreted to represent the dumping of sand from overbank flows. Channel 2 fill is $\sim 13 \mathrm{~m}$ thickness and shows an upward decrease in bed thickness and grain size. The lower fill is high NTG (75\% sandstone) and consists of metre-scale beds which thin towards the easterly dipping margin. The bulk of the lower beds onlaps abruptly against the channel margin, but for each bed a sandstone drape a few centimetres in thickness continues up the erosional bounding surface for a vertical height of 2-3 m. Individual sandstone beds show abrupt grading to siltstone into which subsequent sandstone beds are loaded, particularly in the axial part of the channel fill. The upper channel fill has a lower NTG of $<20 \%$ and consists of thin-bedded sandstones and siltstones. A thinning and fining signature is identified both vertically and laterally from channel axis to margin. Axis to margin changes occur as a transition in lithofacies; individual $5-20 \mathrm{~cm}$ thick rippled sandstone beds are traced over distances of $50-100 \mathrm{~m}$ where they are observed to thin and decrease in grain size to planar-laminated siltstones. Therefore, time lines can be traced from the later stages of axial channel-fill laterally into fine-grained marginal deposits.

Channel 3 has a higher aspect ratio and a shallower gradient channel margin, with a maximum reconstructed angle of $4^{\circ}$. Again, just the western margin is preserved and identified at outcrop by an abrupt change of bed orientation combined with abrupt bed thinning and fining within the infilling strata; there is no erosion identified at the preserved extent of Channel 3. Channel infill occurs in two stages, a $7 \mathrm{~m}$ thick basal sandstoneprone $(>85 \%)$ lower section composed of thickly bedded sandstones, which is overlain by a $5 \mathrm{~m}$ thick sandstone-poor $(<20 \%)$ upper section composed mainly of thinly bedded siltstones with minor discontinuous ripple-topped sandstone beds (Fig 5b). A transition in lithofacies is observed within the basal unit as individual beds approach the channel boundary. This is expressed as a change from $25-150 \mathrm{~cm}$ thick commonly structureless sandstone beds to $5-10 \mathrm{~cm}$ thick ripple-laminated siltstone beds over an outcrop distance of less than $100 \mathrm{~m}$. The upper fine-grained channel-fill is continuous to the west for $200 \mathrm{~m}$ where there is a transition to several sandstones interpreted as an overbank setting (similar to Channel 2 overbank deposits described earlier). The overbank sandstones contain ripple and climbing ripple lamination and, in contrast to the in-channel sandstones, contain plant debris. Beds within the
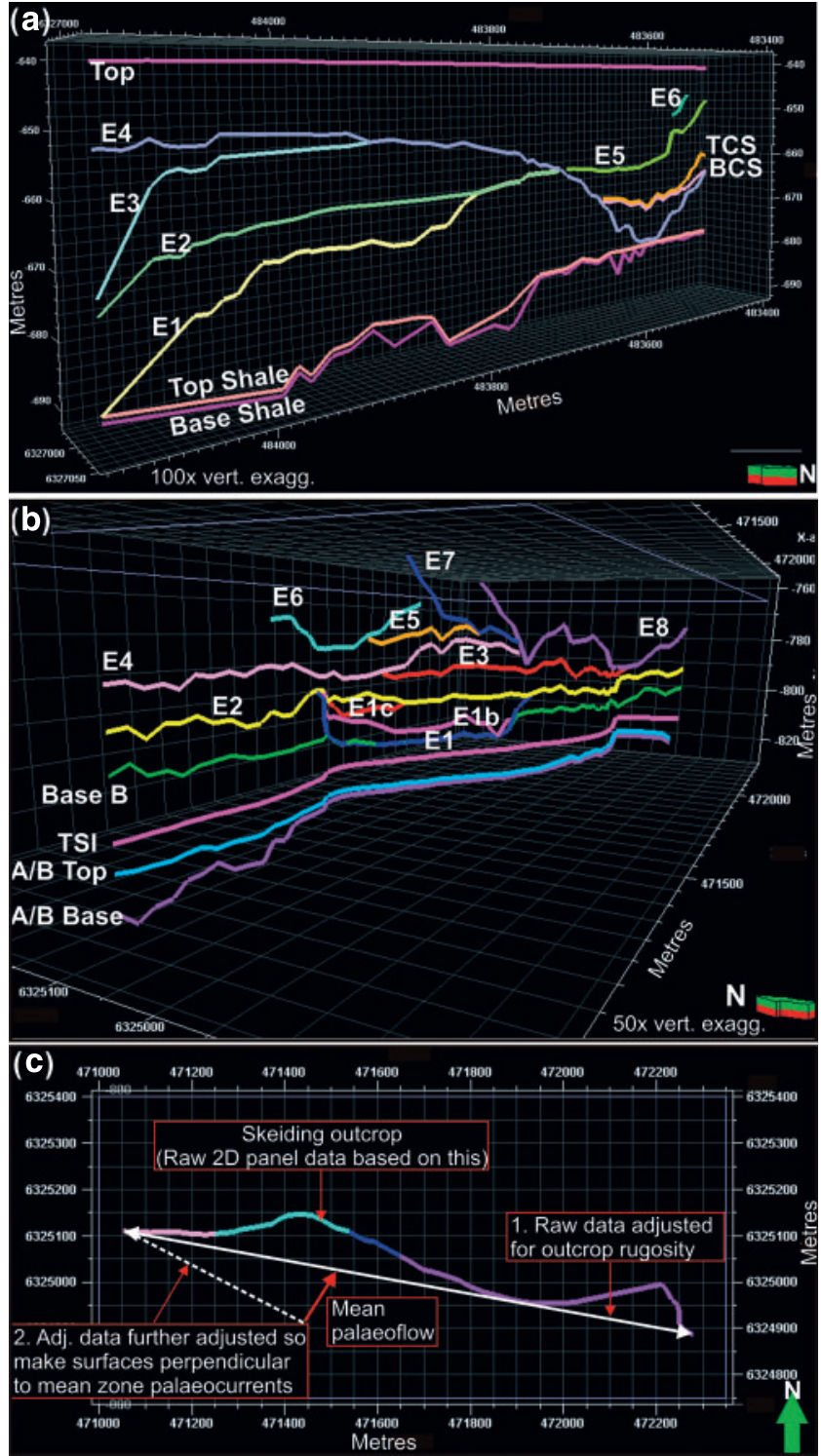

Fig. 10. (a), (b) Oblique views of the dGPS surveyed key stratigraphy surfaces at the Rubbish Dump and Skeiding outcrops, respectively (cf. Figs 4 and 5). Vertical exaggerations are shown. (c) Map-view graphic illustrating the two-step adjustment to correct 2D photopanel sedimentary architecture measurements for (1) outcrop rugosity and (2) mean grouped palaeocurrent directions (see text).

overbank succession dip away from the interpreted axis of the channel with a reconstructed dip of $\sim 2^{\circ}$ to the west. The point of transition from marginal siltstones to overbank sandstones steps to the east as aggradation continued.

Channel 4 is an erosional channel with a steeply dipping margin and forms the most easterly part of the Rubbish Dump outcrop (Fig 5b). Only the western margin is preserved and this incises steeply through $12 \mathrm{~m}$ of Channel 3 strata. The steepest part of the margin is reconstructed at $51^{\circ}$. This steep margin suggests that Channel 4 was cut by higher energy flows or has been oversteepened by gravitational collapse of the channel margin. The fill of the channel feature comprises $15 \mathrm{~m}$ of thin-bedded siltstone, commonly exhibiting discontinuous ripple lamination. The upper $5 \mathrm{~m}$ of fill shows a thickening- and coarsening-upward trend. The majority of these beds thin and fine laterally against the more gently dipping upper part of the margin; however, some of the sandstone beds extend for more than $100 \mathrm{~m}$ beyond the steep erosional confines of Channel 4 . 


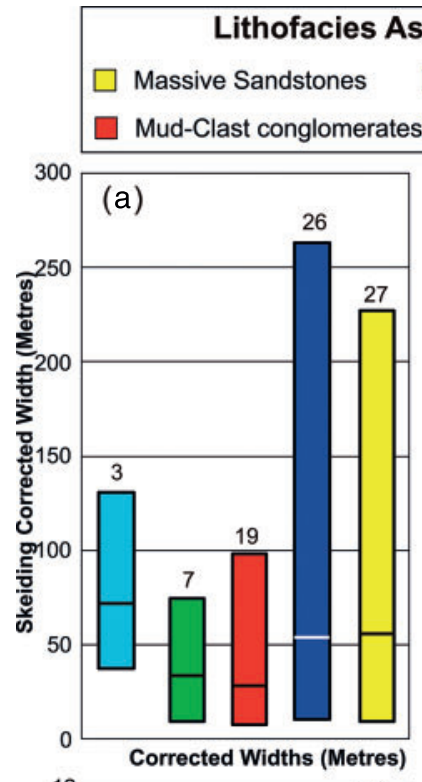

ciations Key:

Thin-bedded Units

Local Slumps $\square$ Regional Slumps
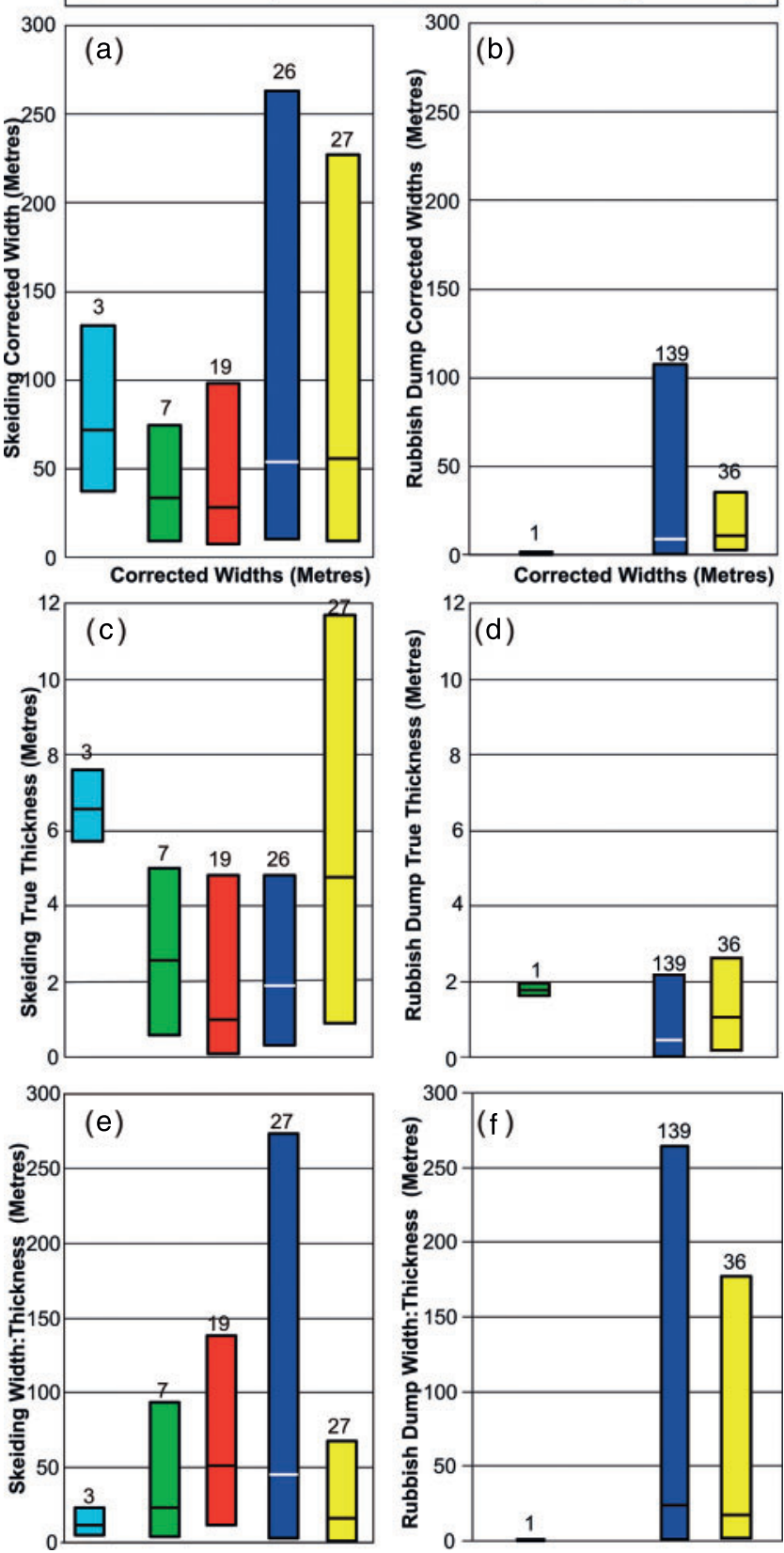

Fig. 11. Bar chart summary statistics of lithofacies associationmeasured architectural geometry data for Skeiding $(\mathbf{a}, \mathbf{c}, \mathbf{e})$ and the Rubbish Dump (b, d, f) outcrops, respectively. Bar charts represent minimum and maximum recorded value, with horizontal line indicating mean values. Top bar numbers indicate number of measurements. Observed bed widths were corrected for outcrop rugosity and mean palaeocurrent direction (Fig. 10c and text).

The younger western channel complex outcrops approximately $500 \mathrm{~m}$ to the west of the axis of the eastern complex and contains the highest NTG fill $(>80 \%)$ of the Rubbish Dump outcrop. The western complex is more complete, retaining both east and west margins and revealing a symmetrical profile. The incisional bounding surface is composite, with several smaller-scale erosion surfaces merging on to the surface. The composite surface erodes down $36 \mathrm{~m}$ to the base of Unit C. The steep-sided and most deeply eroded part of the complex has a corrected width of $>175 \mathrm{~m}$. However, the bounding surface continues as a low angle erosional surface a further $160 \mathrm{~m}$ to the east. Three channel-fills are identified within the complex (Channels 5, 6 and 7); Channels 5 and 6 are separated by a continuous $0.2 \mathrm{~m}$ drape of mudstone and fine siltstone. The fill of Channels 6 and 7 is asymmetrical, the western margins showing a transition from axial amalgamated sandstones to thin-bedded heterolithic marginal lithofacies. At the eastern margin of all three channel-fills, amalgamated sandstones onlap the erosional channel-bounding surface of the complex. Channel 7 is the final fill of the western channel complex, infilling the remaining erosional topography, including the low angle erosional surfaces (and beyond) to form 'channel wings' that extend for the preserved width of the outcrop.

Overlying the channel complex is $7.5 \mathrm{~m}$ of laterally extensive thin-bedded siltstone, which forms the uppermost part of C.2. The thin-bedded unit remains constant in thickness for several kilometres west of the Rubbish Dump. Overlying C.2 is the regionally extensive $2 \mathrm{~m}$ thick 'Upper C mudstone', which separates C. 2 from the $7 \mathrm{~m}$ thick, thin-bedded siltstones of C.3 and forms a datum for correlation.

The four C. 2 channels in the eastern complex show laterally offset to aggradational stacking to the east. As a consequence the preserved stratigraphy consists of a stack of western channel margins. Channel 4, which is filled with siltstone, is thought to represent an abandonment of this phase of channelization. Renewed channelization led to incision of the western complex (Fig. 12b).

\section{Skeiding and Rubbish Dump outcrop summary}

The fill of the Laingsburg Basin documents a gradual shallowing through progradation of a submarine slope system and, consequently, successive stratigraphic units represent a landward migration and shallowing of depositional environments. Unit B at Skeiding is interpreted as a base-of-slope deposit where the downdip change in gradient promoted rapid deposition of high NTG channel fills. Complexes A and B high aspect ratio channels stack vertically in the early high accommodation setting; they are weakly erosional in axial areas, have extensive wings and are associated with large volumes of overbank deposits. Complex $\mathrm{C}$ channels are interpreted to have formed in conditions of very little accommodation space, which forced deep incision of steep-sided low aspect ratio channels and a lateral stacking pattern.

The younger Unit $\mathrm{C}$ is interpreted as a mid to lower slope setting; however, despite a low NTG input to the system, the temporal channel development observed at the Rubbish Dump follows a similar pattern to that of Skeiding. Channels of the Rubbish Dump eastern complex are part confined by axial incision and part by the accumulation of marginal/levee deposits. The eastern channels stack aggradationally with an easterly trajectory. The western complex forms the fill of a composite erosional surface. All deposition is confined within this surface, suggesting a lower accommodation setting, similar to Skeiding Complex C.

\section{RESERVOIR MODELLING}

A key objective of this study was to develop a routine workflow to build 3D reservoir models from digital outcrop data. This process also provides a $3 \mathrm{D}$ quality control feedback loop to the original data.

\section{Deterministic outcrop key horizons}

The structural dip-corrected channel-bounding surfaces in both the Rubbish Dump and Skeiding outcrops were used as 


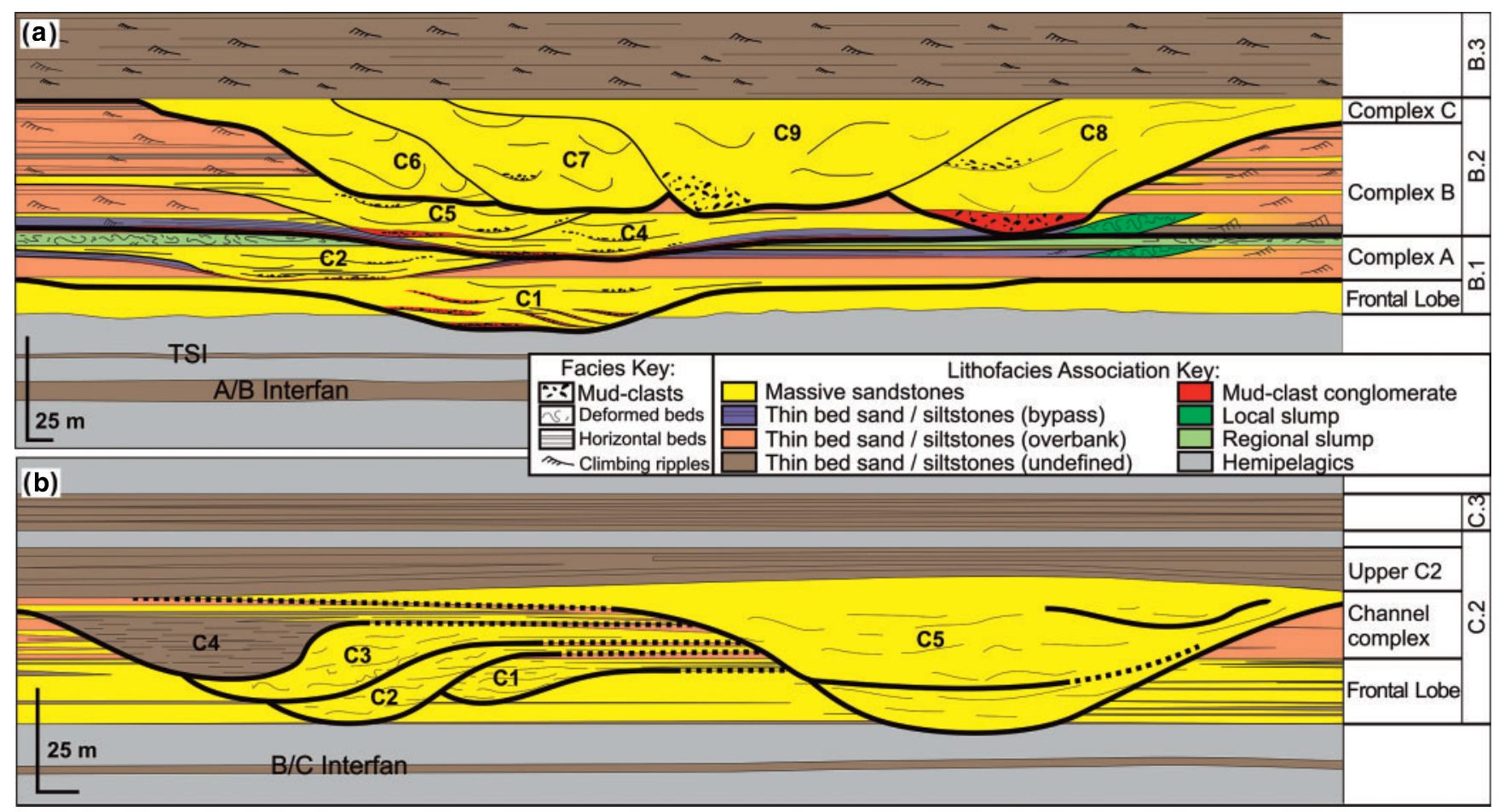

Fig. 12. Schematic reconstruction models showing the interpreted sedimentary evolution of (a) Skeiding and (b) the Rubbish Dump outcrops. (a) Interpreted successive deposition: A-B Interfan and TSI deposited before condensed shales and frontal lobe. Early channels vertically stack before late-stage lateral stacking (C6-9) and abandonment. (b) Interpreted successive deposition: B-C Interfan deposited before condensed shales and frontal lobe. Early channels then laterally-offset stack. Final channel abandonment (C4) siltstone filled. Late-stage channel (C5) eroded as single feature with several stages fill. Final deposition of thin beds $(\mathrm{C} 2 / 3)$ and mudstones.

deterministic zone boundaries for the reservoir models. Up- and downdip of the outcrop section, synthetic zone boundaries were added to generate $3 \mathrm{D}$ surfaces across the whole reservoir model. Whilst initial planar surfaces could be generated by simply keeping the height of each key surface constant and changing the $\mathrm{x}, \mathrm{y}$ value away from the outcrop position, channel-bounding surfaces were extended both 'updip' and 'downdip' from outcrop positions using mean palaeoflow direction for lithofacies within the fills (see 'Digital outcrop model and digital data analysis' section and Table 3 for details). Assumptions were made on the downstream development of each channel element based on field observations of key architectural surfaces, asymmetrical facies distributions and palaeocurrent data, as previously documented, as well as relationships documented in modern systems (e.g. Laberg et al. 2005; Cross et al. 2009; Twichell et al. 2009). The interpreted base-of-slope location of Unit B at Skeiding suggests the channels become more entrenched updip and transition to lobes downdip, albeit beyond the scale of these reservoir models. As the horizons were all dGPS surveyed, they could be imported as $\mathrm{x}, \mathrm{y}, \mathrm{z}$ UTM coordinate positions to create digital zonal surfaces. For the Rubbish Dump model, some channel erosion surfaces were exposed only partly; therefore, these surfaces were extrapolated to the edge of the model, completing the channel architecture using both outcrop information and the sedimentary architecture interpretation (Fig. 12b).

\section{Reservoir model}

Model layers were created between zone boundaries using accepted modelling procedures (Table 4). For example, the hemipelagic mudstone-dominated zones were modelled as one cell thick and across the whole model, whereas the erosive surfaces were usually partially complete and truncated underlying units. Model resolution needed to be high enough to reproduce the sedimentary details observed at outcrop, to be as deterministic as possible but to keep within a manageable number of grid cells. The models, therefore, used cell sizes of $15 \mathrm{~m} \mathrm{x}, \mathrm{y}$ and usually $0.1 \mathrm{~m} \mathrm{z}$ resolution, totalling 5.3 million cells in the $1350 \mathrm{~m}(\mathrm{x}), 800 \mathrm{~m}$ (y) and $50 \mathrm{~m}$ (z) Rubbish Dump

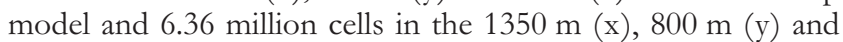
$53 \mathrm{~m} \mathrm{(z)}$ Skeiding model (Table 4 for detail).

Stochastic (object-based) modelling using lithofacies associations was undertaken within each zone to fill the cell model volume. Lithofacies associations were used rather than lithofacies to prevent confusion between different depositional environments and to prevent more than one lithofacies being modelled within the same zone. Care was taken to honour the upscaled well-log lithofacies association percentages and vertical distributions, outcrop-derived lithofacies associations, corrected bed width and thickness data (Fig. 11), and minimum/ mean/maximum palaeocurrent values for each zone. Where initial models created were found to be deficient in certain areas, e.g. lack of palaeocurrent measurements within certain zones, the outcrops were revisited to fill in 'missing' information. Apart from the hemipelagic mudstone-dominated units (e.g. zones one and seven in the Rubbish Dump model and zone one in the Skeiding model), the other zones in both models were split into two end-members and each stochastically modelled separately. End-member one was modelled to have high width-to-thickness ratio units with thin-bedded units predominating at the base and coarsening upwards into erosional channel units. These zones also had small-scale localized slumps modelled within the thin-bedded units, representing slumping of over-steepened channel margins. In contrast, end-member two was modelled on Skeiding Complex C, had 


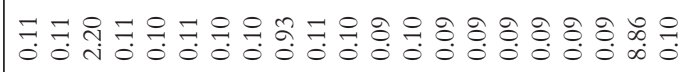

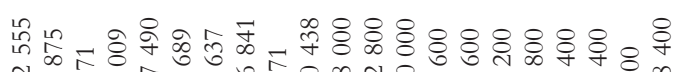

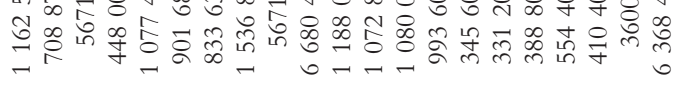

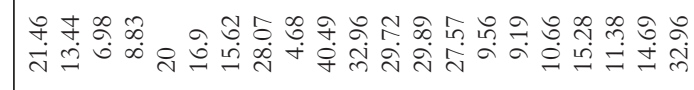

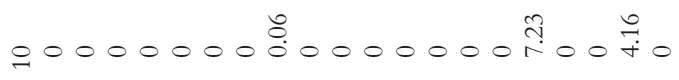

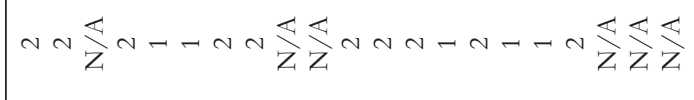

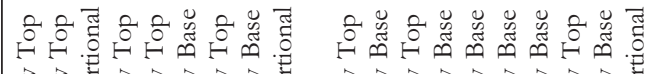

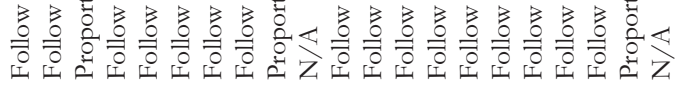

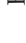

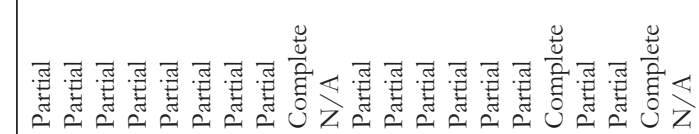

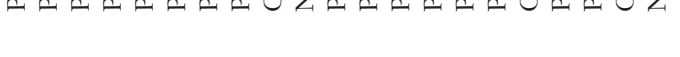

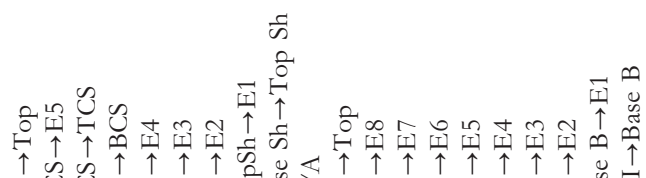

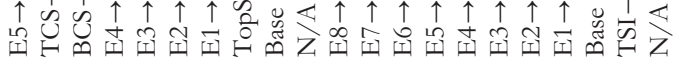
(1)

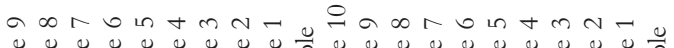

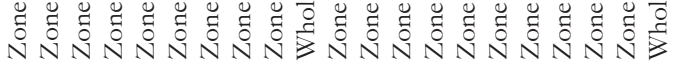

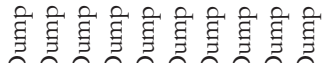

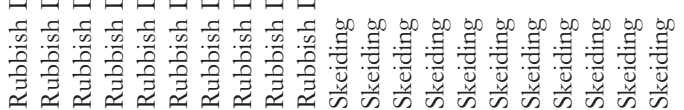


lower width-to-thickness ratios, channels were more sandprone and had a high predominance of basal mudstone rip-up clast lags (Table 4 for details).

Additional model conditioning was necessary to improve the match with outcrop data. For instance, modelling initially placed mudstone clast lags throughout each zone, contrary to their observed positions within only the basal parts of channel fills. Use of the vertical probability curve trend function from the pseudo-well-log lithofacies distributions improved the clast lag placement, but the best results were achieved when applying the probability best-fit curves for each lithofacies association using the upscaled grain sizes obtained from the pseudo-well-logs within each modelled zone. An artificial surface dipping $5^{\circ}$ downflow was also used to bias the stochastic-placement of object-bodies in line with palaeoflow and channel orientation (Fig. 13a). Further modelling could also be undertaken for lithofacies within lithofacies association geobodies, where lithofacies occurred in more than one sedimentary environment. The difficulty of representing both basal bed onlaps and erosion of upper beds within a single zone was solved partially by using the onlap base surface rules and an artificial reference surface (Fig. 13b). Using lithofacies associations could potentially allow lateral lithofacies transitions to be undertaken within these associations. For example, the transition from axial structureless fine-grained sandstones to marginal thin very fine-grained sandstone lithofacies in a single bed was unsuccessful here but would be important to capture in fluid flow simulations. This would be possible by modelling the lithofacies within the facies associations but was not undertaken in this study as static models were not subjected to fluid flow simulations.

\section{Extending the model}

The detailed spatial and temporal variation in deep-water architecture and facies distributions observed at single outcrops in the Laingsburg area generates concepts that may be applicable to larger-scale modelling projects. Regional-scale sedimentary pattern suggests a base-of-slope location for Skeiding, gradually modified through normal slope progradation and can be applied to predict deposit character in areas up- and downdip; that is, increased gradient updip and decreased gradient towards the basin floor. Based on this assumption, it is expected that updip of Skeiding increased flow efficiency and sediment bypass will have led to greater incision of channel elements. Low aspect ratio channel elements would be expected and lateral stacking of channels elements may also show the greatest sinuosity. Downdip of Skeiding, rapid rates of sedimentation are likely to force a more aggradational high aspect ratio channel format with increasing quantities of overbank deposition as part of the transition to lobe depositional architecture.

\section{Model calibration}

Analysis of the architecture of key stratigraphic surfaces and individual lithofacies associations (Fig. 11) was undertaken from the correlation panels and used as direct input to reservoir models. The outcrop photomontages provided important understanding of the key stratigraphic surfaces and sedimentary evolution and were used to position the acquired logs (Figs 4a, $5 a)$. Initial models created were found to be deficient in certain areas (e.g. lack of palaeocurrent measurements within certain zones) and, therefore, the outcrops were revisited to fill in 'missing' information. The final models used the key, structurally corrected stratigraphic surfaces as deterministic zone boundaries using the observed erosional and aggradational relationships observed in the field (Table 3). A combination of pseudo-well-log information and extracted lithofacies association bed statistics then stochastically populated the models. Subsequent model refinements, including biasing the position of mud-clast conglomerate channel lag lithofacies to the base of channels, using artificial surfaces to create sub-horizontal channel lithofacies bodies and separately modelling different zones depending upon their observed depositional character (Fig. 13), all improved the model match to the observed and interpreted geology (Fig. 12).

\section{Model to model comparison}

Connectivity analysis of object bodies crossing zone boundaries was comparable for both models $71.7 \%$ for Skeiding vs. $77.5 \%$ for Rubbish Dump), as were sandstone body connectivities (99.5\% vs. $99.84 \%$ ). However, if key surfaces were a barrier to fluid flow, as would be expected with thin-bedded heterolithic and mudstone units, then the resulting connectivities would be significantly different $(23.3 \%$ versus $31.5 \%$ for the Skeiding and Rubbish Dump models, respectively). The Skeiding model channels are not only thicker $(19 \mathrm{~m}$ vs. $15 \mathrm{~m}$ averages $)$ and wider (227 m vs. $95 \mathrm{~m}$ averages), but also have higher proportions of sandstones $(74.8 \%$ vs. $54.6 \%)$ and mud-clast conglomerate units $(2.8 \%$ vs. $0.05 \%)$ and lower proportions of thinbedded units $(12.5 \%$ vs. $44.7 \%)$ when compared to Rubbish Dump model channels (Fig. 14). Comparing the western and eastern Skeiding channel complex lithofacies proportions, some are also quite different; $(64.6 \%$ vs. $84.9 \%$ for sandstones and $13.8 \%$ vs. $9 \%$ for thin-bedded units), and $19 \%$ vs. $4 \%$ of local and regional slump units. Semi-variograms were also generated for both models (Fig. 15). These are commonly used in reservoir modelling studies (e.g. Howell et al. 2008) and can give a good indication of a reservoir's potential 3D connectivity and continuity (Hovadik \& Larue 2007). Resulting variograms may be used to control subsequent petrophysical property addition for fluid simulations (work not undertaken here). Common ranges of $1000 \mathrm{~m}$ main direction, $50 \mathrm{~m}$ vertical range, $60^{\circ}$ tolerance angle and mean palaeocurrent directions were used for each of the models. Results showed similarly-shaped regression curves, albeit longer ranges ( 533 vs. 667), sill (0.825 vs. 2.09) and high nugget values (0.21 vs. 0.295$)$ for the Skeiding model compared to the Rubbish Dump model, respectively.

\section{Model comparisons with outcrop}

The generated Skeiding (Fig. 13a) and Rubbish Dump models (Fig. 13b) were built with similar dimensions $(1350 \mathrm{~m} \times$ $800 \mathrm{~m} \times 50 \mathrm{~m}$ ) and comparable data input types, including sedimentary log density and outcrop-derived depositional architectures. However, the Skeiding outcrop provided much better $3 \mathrm{D}$ control than the Rubbish Dump due to a more rugose outcrop. The Rubbish Dump model thus required further conditioning using field data to extend the model beyond the line of the outcrop; for example, key digitally captured erosional surfaces were extended parallel to palaeoflow to create a geologically realistic model (Fig. 13a). Comparisons of lithofacies association distributions within the models compared to outcrop generally showed a good agreement (cf. Figs 4, 5, 16) although obviously their distribution and number were more simplistic within the reservoir model. However, experience gained in the Laingsburg slope succession suggests that a 'one model fits all' approach to modelling may not be applicable to both low and high NTG channel systems. By comparing the Skeiding and Rubbish Dump outcrops and models built from the resulting data, we aim to illustrate the limitations 


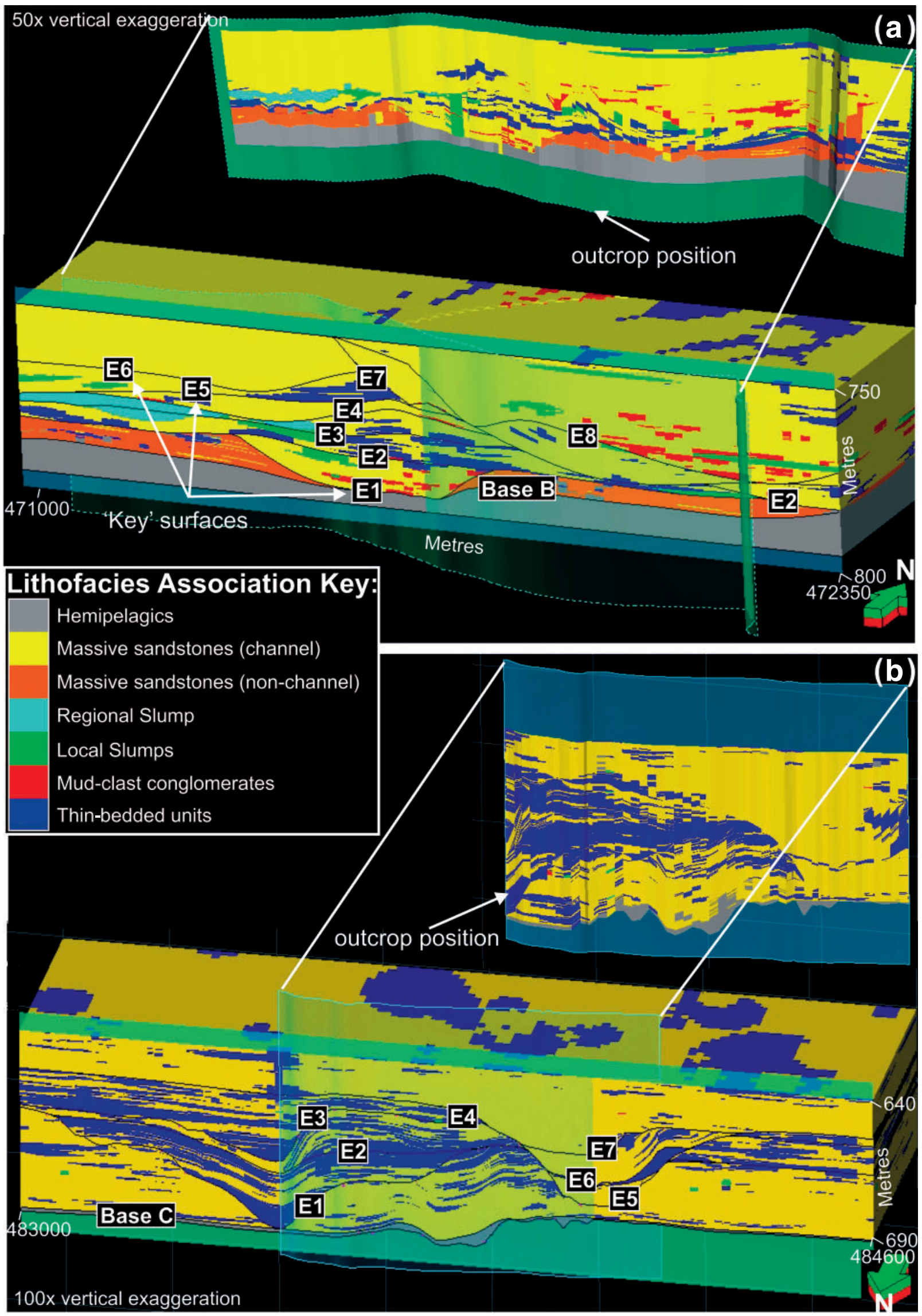

Fig. 13. Screen-grabs of the generated reservoir models showing (a) Skeiding and (b) Rubbish Dump models, with labelled key stratigraphic surfaces. Both models have been shown with the cross-section approximately in the same position as the outcrop data (exploded for both models). 
Final version can be found at http://pg.geoscienceworld.org/cgi/content/abstract/16/4/307

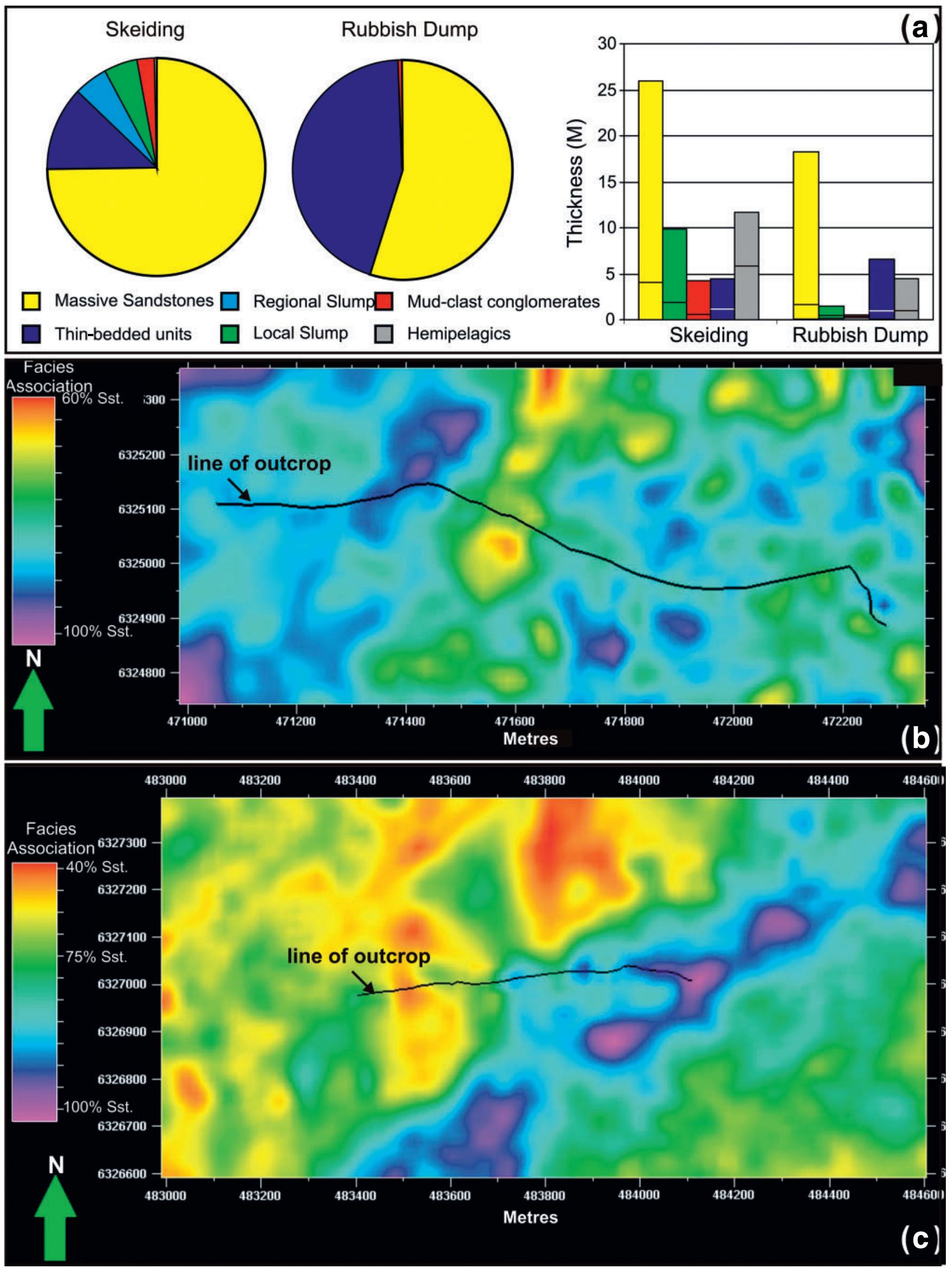

Fig. 14. (a) Reservoir model lithofacies association proportion pie-charts and bar chart histogram thickness plots for channel intervals only. (b) Map-view average lithofacies association plots of Skeiding and (c) Rubbish Dump models, produced by summing lithofacies association types in each grid vertical pillar/number of cells (see colour bars). Outcrop positions are shown in (b) and (c) with model extended away from these positions based on key architectural surfaces, asymmetrical facies distributions and palaeocurrent data (see text). 
(a)
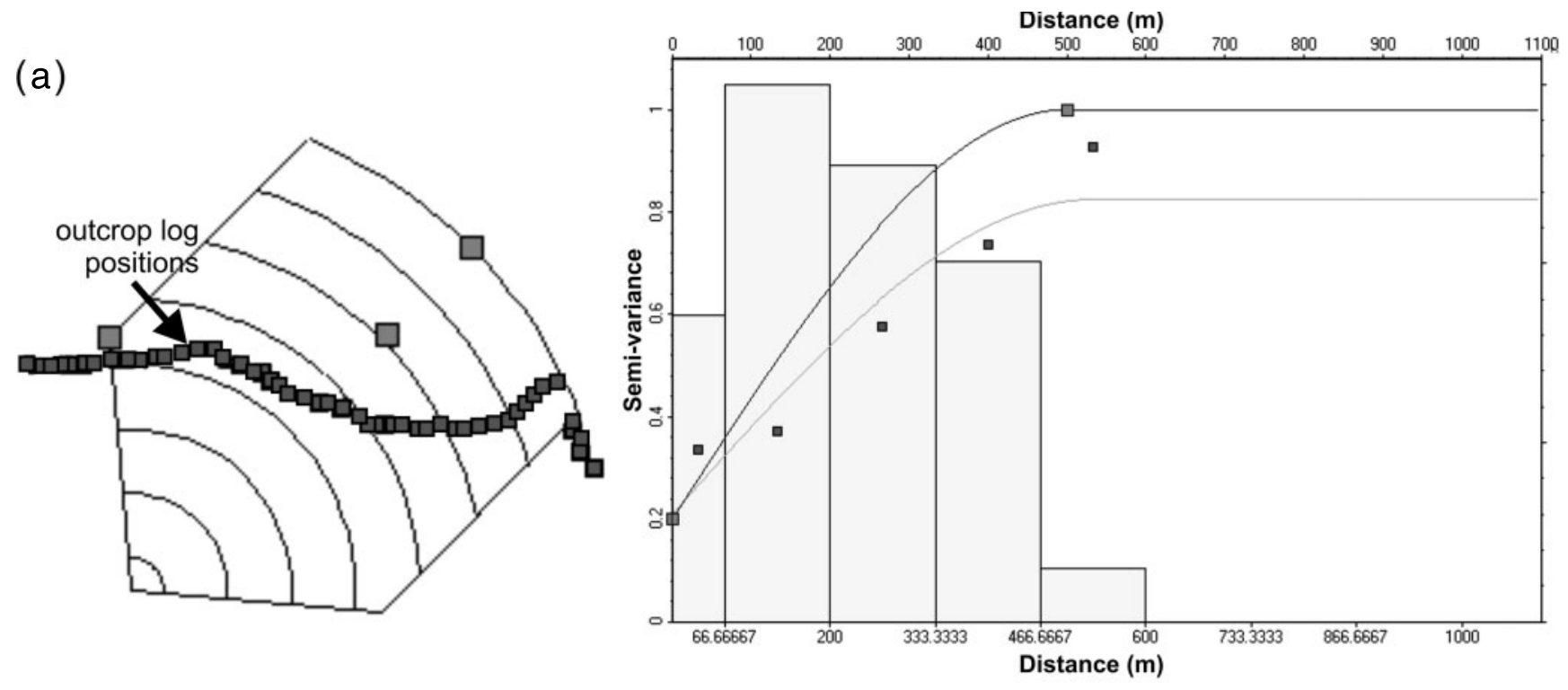

(b)
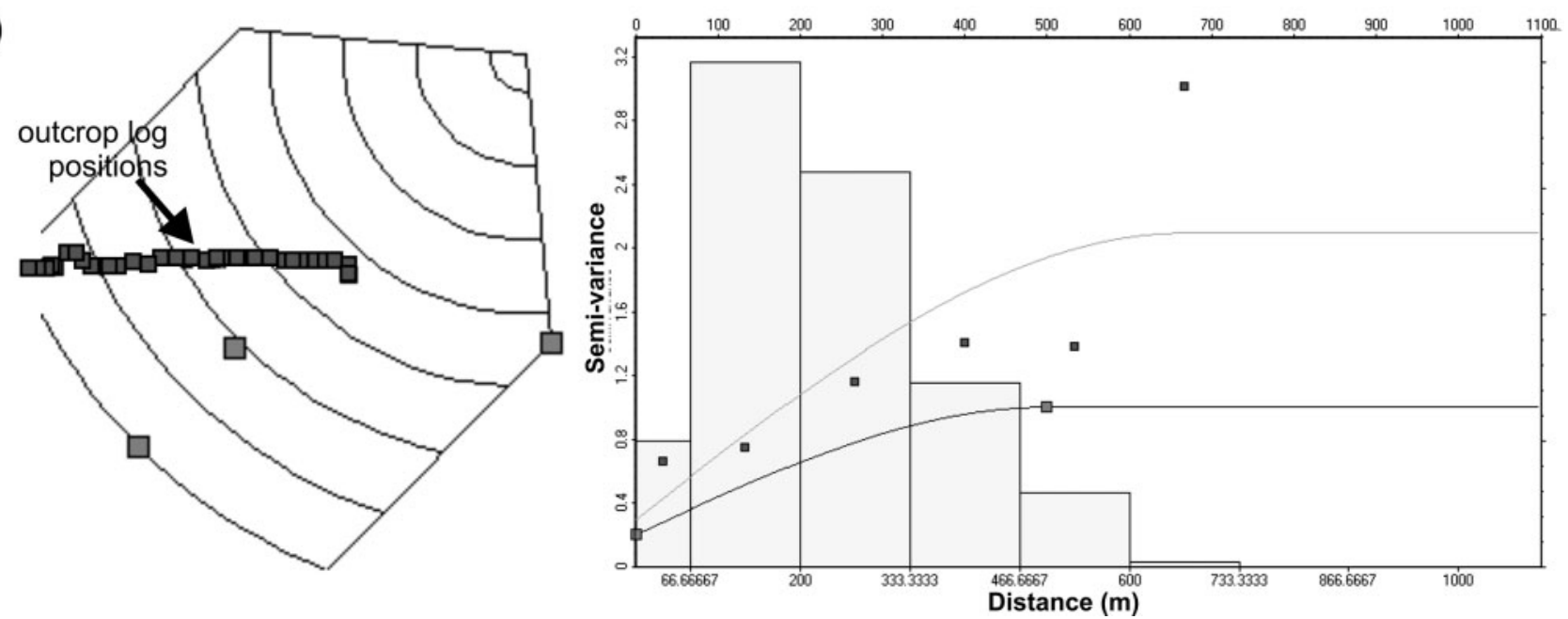

Fig. 15. Map-views of semi-variogram sampling areas (pseudo-well-log positions shown) and regression curves generated at the same scales from (a) Skeiding and (b) Rubbish Dump reservoir models, respectively (see text).

encountered in accurately characterizing the features observed in low NTG systems.

\section{Workflow}

The workflow (Fig. 17) for routinely creating reservoir models using the outcrop-derived key master surfaces, extracted lithofacies association architectures and structurally corrected, grouped palaeocurrent measurements allows fuller utilization of outcrop analogues in reservoir geology and engineering. Rather than solely a source of quantitative conditioning information, the outcrop becomes a true $3 \mathrm{D}$ analogue to the reservoir being studied. Modelling interrogation routines, such as connectivity analysis, well planning, seismic forward modelling and (with addition of realistic rock and fluid property information), fluid flow simulation and dynamic testing, all become possible.

\section{DISCUSSION}

Reservoir modelling of high sandstone percentage channel systems

Dimensions within the Skeiding base-of-slope channel system are comparable to many hydrocarbon-producing high NTG channel systems, such as the Gulf of Mexico (e.g. Mayall et al.
2006) and offshore Nigeria (e.g. Armentrout et al. 2000). Submarine channel initiation is often recorded as occurring through slope incision, which progressively becomes more focused (e.g. Gee et al. 2007; Cross et al. 2009). At Skeiding, initial clastic deposition occurs within a strongly depositional lobe environment. The lobe may be related to the advancement of the slope channel and frontal splay, as observed in the Amazon Fan (potentially analogous to the HARP seismic facies of Pirmez \& Flood 1995; Lopez 2001). The positive relief due to lobe aggradation is incised as the channel system advances basinward (Channel 1). The overlying Channels 2-9 follow a motif of increasing erosional depth and decreasing aspect ratio, a similar pattern to channels observed on the Angolan margin (Gee et al. 2007). Changes in channel sections are combined with an upward change in stacking patterns; Channels 1-5 stack vertically and Channels 6-9 laterally. Similar examples of changes in stacking pattern are observed in seismic data (e.g. Gee et al. 2007) and may reflect more closely the evolution of a more sinuous planform over time; however, Mayall et al. (2006) noted that channel stacking patterns can vary over relatively short downdip distances. The thin-bedded external levee deposits that form the upper part of the Skeiding outcrop do not form part of the reservoir model. 


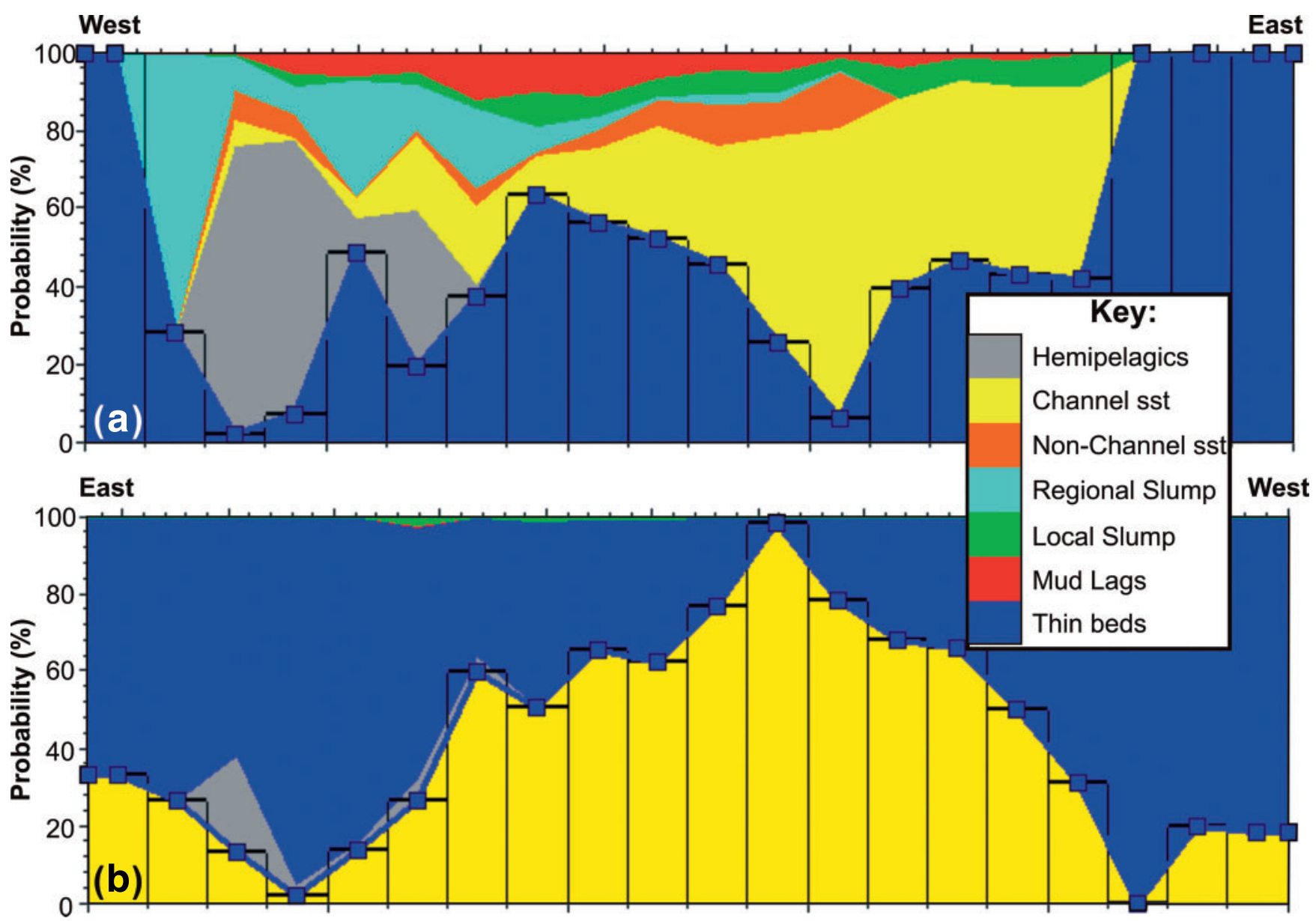

Fig. 16. Lithofacies association (see key) probability curves across (a) Skeiding and (b) the Rubbish Dump reservoir models at approximately the same positions as the respective outcrops.

Infill of Channels $2-5$ consists of a thin-bedded siltstone bypass facies, which is overlain and cut out in the axial region by overlying erosive-based structureless sandstones that form the bulk of the channel fill. The overlying thinly-bedded silt bypass lithofacies have the potential to provide discontinuous baffles or barriers to flow. However, without the spatial context gained at outcrop, the stratigraphic base of the channels would have been picked at the first thick sandstones, thereby ignoring the earlier bypass lithofacies. Field data were used to characterize the extent of the bypass lithofacies and bias it into a realistic position at the basal part of the channel elements. This can be difficult with log data alone, where there are significant proportions of mud-clast conglomerates present. Accurate modelling of the extent and positioning of the facies produced by each stage of channel infill provided a more realistic approximation of the vertical communication between adjacent channel elements. The youngest channels (6-9) at Skeiding are of a low aspect ratio and stack laterally. Infill of these channels is predominantly structureless sandstone. At model scale the structureless sandstone fill approximates to lateral and vertical homogeneity and presents few issues for modelling. However, Channels 6-9 incise downward from a similar stratigraphic level and there is little to distinguish between the fill of individual channels. In the subsurface they would probably be imaged as a single thick sheet sandstone, hence underestimating the complexity of the system. The modelled orientation of each Skeiding channel is dictated by a combination of outcrop pattern and sole mark-derived palaeocurrents. At Skeiding, channel elements are amalgamated together; however, downdip projections suggest divergence of the channels. This has implications for connectivity of the larger system, but is beyond the scope of this paper.

\section{Reservoir modelling of low sandstone percentage} channel systems

The Rubbish Dump system presents more of a modelling challenge. In contrast to other fine-grained slope systems (e.g. the Nile Delta; Samuel et al. 2003; Cross et al. 2009), incision is not initiated at the Rubbish Dump system with the introduction of clastic sediment; rather it is underlain by a package of thick amalgamated sheet sandstones which thin and fine laterally away from the eastern Dump and are interpreted as frontal lobe deposits. The lobe is incised by two channel complexes; the eastern complex features low NTG heterogeneous sand/ siltstone channel-fills which stack aggradationally with a slight easterly trajectory and the younger western complex which is deeply entrenched and is infilled with high NTG channel-fills that stack vertically. The lobe overlain by channel pattern may again be analogous to the HARP seismic facies described in the Amazon Fan (Pirmez \& Flood 1995; Lopez 2001).

Within the eastern complex, channel margins are observed in exceptional detail and at many times higher resolution than currently available in seismic imagery. Observations detail conspicuous changes occurring in the morphology of the margin and the character of infilling facies as each channel is filled. Each channel shows an incisional relationship with the substrate in the axial areas, incising in the order of 5-10 m. 


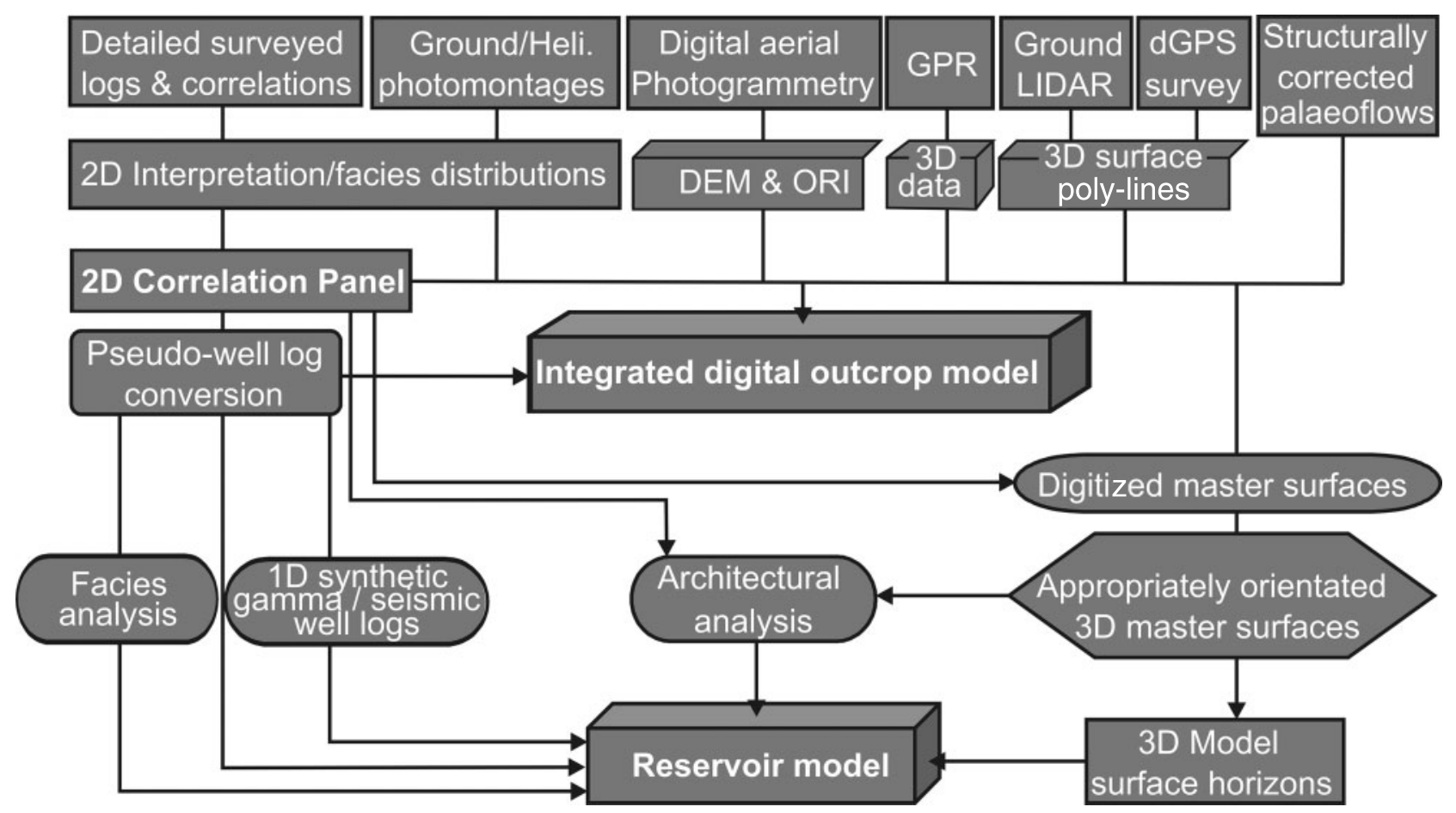

Fig. 17. Specific workflow used for this study. Input data (top row) were digitized and integrated into a single digital outcrop model (3D box). Log correlation panel then digitized to pseudo-well-logs. Reservoir models (3D box) then created using input information (see text). DEM, digital elevation model; ORI, ortho-rectified image; dGPS. differential Global Positioning System.

Early fill is typically thick-bedded sandstones, which are amalgamated in the axial regions and thin before pinching-out against the steep incisional margins. The upper, younger fill of the same channel elements is a similar thickness of $5-10 \mathrm{~m}$ and can show marked lithology changes where individual beds fine from $85 \%$ sandstone in the channel axis to $15 \%$ sandstone over lateral distances of less than $100 \mathrm{~m}$. These lateral changes are thought to represent the transitional upper low-gradient margin of the channel where there is no defined erosional margin, and late-stage channel deposits are contemporaneous with overbank deposits. When interpretations of seismic data acquired over similar depositional systems are based on the distribution of sandstone, sharp boundaries may be placed at the margins of these channels. However, this study suggests that the type of transitional margins documented at the Rubbish Dump may be common in low NTG systems. The connectivity must be accounted for, in particular when considering the leakage of hydrocarbons from sand-rich axial fill (e.g. Fig. 3a) into genetically related marginal lithofacies of lower reservoir quality (e.g. Fig. 3d). With current techniques this is difficult to achieve; where a channel element is modelled as a single 'zone' it cannot be modelled to have fluid connectivity with only a fraction of its margin.

The entire infill of the Rubbish Dump western complex is younger than the adjacent strata. Complete cross-sectional preservation of the channel-fills of the western complex provides an opportunity to observe lithofacies asymmetry. Channel 5 is symmetrical in terms of lithofacies and margin gradient. Channels 6 and 7 have incised eastern margins suggestive of a cut margin, against which structureless sand was deposited, while the western margins are transitional to thin-bedded heterolithic lithofacies which in turn pinch out against the western erosional bounding surface of the channel. This depositional pattern suggests a cross-channel gradient from thalweg to a lower energy inner-bank environment set up by curvature within the channel planform and may be used to deduce that the western complex curved round to a more northerly trajectory in the locality of the Rubbish Dump. The observed increase in asymmetry between Channels 5 and 7 is indicative of an increasing gradient in bed shear stress and may be a result of increasing bend amplitude over time (e.g. Peakall et al. 2000). Similar to the late Skeiding Complex $\mathrm{C}$ channels, the bulk structureless and consistent grain-size sandstone fill of the western complex presents few problems for reservoir modelling. However, complex-scale vertical permeability is probably affected by the presence of the thin siltstone and mud separating Channels 5 and 6 , although, in three dimensions the presence of this layer is likely to be localized and dependent on the level of erosion beneath Channel 6 .

\section{Further work}

Further modelling would use the integrated high-resolution dataset shown in this paper to condition a comparative static reservoir model built with $3 \mathrm{D}$ seismic data and well information alone. Lithofacies (and their associated permeability values) would be modelled to gain lateral facies transitions and more realistic reservoir models to be generated. These suggested steps would hopefully gain understanding of upscaling modelling issues, potential well placements and recovery strategies.

\section{CONCLUSIONS}

Two exhumed submarine channel systems from different slope depositional settings with different sandstone proportions were modelled using a range of digital data collection techniques within a single, accurate 3D spatial coordinate system. Multiscale digital models were generated from the raw datasets without the loss of resolution, enabling complicated stratigraphic relationships to be investigated for individual outcrops. 
A common trend in the architecture of both systems is a stratigraphic transition from early aggradational high aspect ratio channels with associated overbank/levee deposits to late-stage deeply incised low aspect ratio channels with limited or no overbank deposition. This is accompanied with an overall increase in the sandstone proportion of infill preserved. A contrasting trend is seen at the lower slope depositional setting at Skeiding where late-stage channels laterally aggrade whereas they vertically stack at the base-of-slope depositional setting at the Rubbish Dump. These architectures were honoured in the reservoir models.

The younger Unit C system is different to many exposed submarine channel-fills due to the low proportion of sandstone preserved in the eastern channel complex. The lateral and weak aggradational stacking patterns of Channels 1-4 have led to the preservation of thin-bedded channel margin lithofacies. There is stratigraphic continuity from the channel-fill to the overbank, and the stacking patterns and connectivity were honoured in the reservoir model.

The channel-fills in the western channel complex preserve asymmetry in lithofacies that might be linked to channel sinuosity. The asymmetry of channel margins and the distribution of lithofacies are important parameters to account for in reservoir models, and have been achieves here.

In comparison, the older Unit B system at Skeiding is more sand-prone. Here, the stratigraphic change in stacking pattern, channel aspect ratio, overbank preservation and lithofacies of channel-fill were all accounted for to produce a more complicated and realistic reservoir model than would be constructed using seismic data alone.

Targeted analysis of the model was able to provide quantitative data at similar scales for a diverse range of topics from sedimentary architecture geometries, lithofacies extent/ proportions to palaeocurrent distributions. The benefits of using a multi-technique data collection methodology were illustrated in this paper. The step of converting the outcropderived data into typical hydrocarbon industry data (e.g. into synthetic 1D gamma-ray and seismic logs) and building detailed reservoir models provided a critical check that collected field datasets are both usable and useful to reservoir modellers.

Further work is suggested to use data with reservoir models built using high-resolution 3D seismic data, and model lithofacies (and their associated permeabilities) separately within the already modelled lithofacies associations. Potential well placements and recovery strategies would then be undertaken and compared to existing models to determine the added benefit gained from this proposed workflow.

The authors gratefully acknowledge Christo Matthee for permission to conduct the field investigation within the boundaries of Baviaans farm. Carlos Oliveira, Chris Haigh, John Kavanagh and Claudio di Celma are thanked for their assistance in the field. De Ville Wickens is acknowledged for logistical support. Dave Hodgetts of Manchester University is thanked for donation of VRGSTM software. Julian Clark of Chevron is thanked for providing Microsoft Excel synthetic gamma-ray log generation macros. Chris Banks and Schlumberger are thanked for providing Petrel ${ }^{\mathrm{TM}}$ technical support and software donation, respectively. The Liverpool University SLOPE2 Project consortia sponsors (BP, BHPBilliton, Chevron, ConocoPhillips, ExxonMobil, Statoil, Maersk, Murphy, Petrobras, Shell, Total, Verbundnetz Gas Norge and Woodside) are acknowledged for financial support and technical input.

\section{REFERENCES}

Armentrout, J.M., Kanschat, K.A., Meisling, K.E. et al. 2000. Neogene turbidite systems of the Gulf of Guinea continental margin slope, offshore Nigeria. In: Bouma, A.H. \& Stone, C.G. (eds) Fine-grained turbidite systems.
American Association of Petroleum Geologists Memoir 72/Society of Sedimentary Geology Special Publication, 68, 93-108.

Arnot, M.J., Lewis, J.M. \& Good, T.R. 1997. Photogeological and imageanalysis techniques for collection of large-scale outcrop data. Journal of Sedimentary Research, 67, 984-987.

Bakke, K., Gjelberg, J. \& Petersen, S.A. 2008. Compound seismic modelling of the Ainsa II turbidite system, Spain: Application to deep-water channel systems offshore Angola. Marine \& Petroleum Geology, 25, 1058-1073.

Bellian, J.A., Kerans, C. \& Jennette, D.C. 2005. Digital outcrop models: applications of terrestrial scanning LIDAR technology in stratigraphic modelling. Journal of Sedimentary Research, 72, 166-176.

Beyer, L.R. 2001. Rapid 3-D screening with seismic terrain: deepwater Gulf of Mexico examples. The Leading Edge, 20, 386-395.

Clark, J.D. 1995. Detailed Section across the Ainsa II Channel Complex, South Central Pyrenees, Spain. In: Pickering, J.T., Hiscott, R.N., Kenyon, N.H., Ricci Lucchi, R. \& Smith, R. (eds) Atlas of Deep Water Environments: Architectural Style in Turbidite Systems. Chapman \& Hall, London, 139-144.

Clegg, P., Trinks, I., McCaffrey, K. et al. 2005. Towards the virtual outcrop. Geoscientist, 15, 8-9.

Cole, D.I. 1992. Evolution and development of the Karoo Basin. In: De Wit, M.J. \& Ransome, I.G.D. (eds) Inversion tectonics of the Cape Fold Belt, Karoo and Cretaceous Basins of Southern Africa. Balkema, Rotterdam, 87-99.

Coleman, J.L., Browne, G.H. \& King, P.R. 2000. The inter-relationships of scales of heterogeneity in subsurface, deep water $E$ \& P Projects - Lessons learned from the Mount Messenger Formation (Miocene), Taranaki Basin, New Zealand. In: Weimar, P., Bouma, A.H. \& Perkins, B.F. (eds) GCSSEPM Foundation, 20th Annual Research Conference Proceedings, Deep-Water Reservoirs of the World, 3-6 December, Houston, USA, 263-283.

Cronin, B., Owen, D., Hartley, A. \& Kneller, B. 1998. Slumps, debris flows and sandy deep-water channel systems: Implications for the application of sequence stratigraphy to deep water clastic sediments. Journal of the Geological Society, London, 155, 429-432.

Cross, N.E., Cunningham, A., Cook, R.J., Taha, A., Esmaie, E. \& El Swidan, N. 2009. Three-dimensional seismic geomorphology of a deep-water slope-channel system: The Sequoia field, offshore west Nile Delta, Egypt. American Association of Petroleum Geologists Bulletin, 93, 1063-1086.

Elliott, T. 2000. Depositional architecture of a sand-rich, channelised turbidite system: the Upper Carboniferous Ross Sandstone Formation, Western Ireland. In: Weimar, P., Bouma, A.H. \& Perkins, B.F. (eds) GCSSEPM Foundation 20th Annual Research Conference Proceedings, Deep-Water Reservoirs of the World, 3-6 December, Houston, USA, 342-373.

Fabuel-Perez, I., Hodgetts, D. \& Redfern, J. 2010. Integration of digital outcrop models (DOMs) and high resolution sedimentology - workflow and implications for geological modelling: Oukaimeden Sandstone Formation, High Atlas (Morocco). Petroleum Geoscience, 16, 133-154.

Falivene, O., Arbués, P., Howell, J., Muňoz, F. \& Marzo, M. 2006. Hierarchical geocellular facies modelling of a turbidite reservoir analogue from the Eocene of the Ainsa basin, NE Spain. Marine \& Petroleum Geology, 23, 679-701.

Figueiredo, J., Hodgson, D., Flint, S.S. \& Kavanagh, J.P. 2010. Depositional environments and sequence stratigraphy of an exhumed Permian muddominated submarine slope succession, Karoo Basin, South Africa. Journal of Sedimentary Research, 80, 97-118.

Flint, S.S., Hodgson, D.M., Sprague, A.R. et al. 2010. Depositional architecture and sequence stratigraphy of the Karoo basin floor to shelf edge succession, Laingsburg depocentre, South Africa. Marine \& Petroleum Geology, DOI: 10.1016/j.marpetgeo.2010.06.008.

Gartner, G.L. \& Schlager, W. 1999. Discriminating between onlap and lithologic interfingering in seismic models of outcrops. American Association of Petroleum Geologists Bulletin, 83, 952-971.

Gee, M.J.R., Gawthorpe, R.L., Bakke, K. \& Friedmann, S.J. 2007. Seismic geomorphology and evolution of submarine channels from the angolan continental margin. Journal of Sedimentary Research, 77, 433-446.

Geehan, G. \& Underwood, J. 1993. The use of length distributions in geological modelling. In: Flint, S.S. \& Bryant, I.D. (eds) The geological modelling of bydrocarbon reservoirs and outcrop analogues. International Association of Sedimentologists Special Publication, 15, 205-212.

Gluyas, J. \& Swarbrick, R. 2004. Petroleum Geoscience. Blackwell, Oxford.

Grecula, M. 2000. Stratigraphy and architecture of tectonically controlled turbidite systems, Laingsburg Formation, Karoo Basin, South Africa. PhD thesis, University of Liverpool, UK.

Grecula, M., Flint, S., Wickens, H. de V. \& Johnson, S. 2003. Upwardthickening patterns and lateral continuity of Permian sand-rich turbidite channel-fills, Laingsburg Karoo, South Africa. Sedimentology, 50, 831-853.

Hodgetts, D., Drinkwater, N.J., Hodgson, D.M. et al. 2004. Three dimensional geological models from outcrop data using digital data collection 
techniques: an example from the Tanqua Karoo depocentre, South Africa. In: Curtis, A. \& Wood, R. (eds) Geological Prior Knowledge. Geological Society, London, Special Publications, 239, 457-475.

Hovadik, J.M. \& Larue, D.K. 2007. Static characterizations of reservoirs: refining the concepts of connectivity and continuity. Petroleum Geoscience, 13, 195-211.

Howell, J.A., Skorstad, A., MacDonald, A. et al. 2008. Sedimentological parameterization of shallow-marine reservoirs. Petroleum Geoscience, 14, 17-34.

Johnson, M.R. 1991. Sandstone petrography, provenance and plate tectonic setting in Gondwana context of the south-eastern Cape Karoo Basin. South African Journal of Geology, 94(2/3), 137-154.

Jol, H.M., Bristow, C.S., Smith, D.G. et al. 2003. Stratigraphic imaging of the Navajo Sandstone using ground-penetrating radar. The Leading Edge, 22, 882-887.

Jones, J.R., Scott, A.J. \& Lake, L.W. 1984. Reservoir characterization for numerical simulation of Mesaverde Meanderbelt Sandstone, Northwestern Colorado. Paper SPE13052. In: Proceedings of the SPE 59th Annual Technical Conference, 1-13.

Jones, R.R., McCaffrey, K.J.W., Clegg, P. et al. 2009. Integration of regional to outcrop digital data: $3 \mathrm{D}$ visualisation of multi-scale geological models. Computers \& Geosciences, 35, 4-18.

Kolla, V., Posamentier, H.W. \& Wood, L.J. 2007. Deep-water and fluvial sinuous channels - Characteristics, similarities and dissimilarities, and modes of formation. Marine and Petroleum Geology, 24, 388-405.

Laberg, J.S., Vorren, T.O., Kenyon, N.H. et al. 2005. A modern canyon-fed sandy turbidite system of the Norwegian continental margin. Norwegian Journal of Geology, 85, 267-277.

Labourdette, R. \& Bez, M. 2010. Element migration in turbidite systems: Random or systematic depositional processes. American Association of Petroleum Geologists Bulletin, 94, 345-368.

Labourdette, R., Crumeyrolle, P. \& Remacha, E. 2008. Characterisation of dynamic flow patterns in turbidite reservoirs using 3D outcrop analogues: example of the Eocene Morillo turbidite systems (south-central Pyrenees, Spain). Marine \& Petroleum Geology, 25, 255-270.

Lien, T., Walker, R.G. \& Martinsen, O.J. 2003. Turbidites in the Upper Carboniferous Ross Formation, western Ireland: reconstruction of a channel and spillover system. Sedimentology, 50, 113-148.

Lopez, M. 2001. Architecture and depositional pattern of the Quaternary deep-sea fan of the Amazon. Marine and Petroleum Geology, 18, 479-486.

Luthi, S.M., Hodgson, D.M., Geel, C.R. et al. 2006. Contribution of research borehole data to modelling fine-grained turbidite reservoir analogues, Permian Tanqua-Karoo basin floor fans (South Africa). Marine and Petroleum Geology, 12, 175-190.

Mayall, M., Jones, E. \& Casey, M. 2006. Turbidite channel reservoirs - key elements in facies prediction and effective development. Marine and Petroleum Geology, 23, 821-841.

McCaffrey, K.J.W., Jones, R.R., Holdsworth, R.E. et al. 2005. Unlocking the spatial dimension: digital technologies and the future of geoscience fieldwork. Journal of the Geological Society, London, 162, 1-12.

Nilsen, T., Shew, R., Steffens, G. \& Studlick, J. 2008. Atlas of Deep-Water Outcrops. American Association of Petroleum Geologists, Studies in Geology (ST) 56

Olariu, M.I., Ferguson, J.F., Aiken, C.L.V. \& Xu, X.M. 2008. Outcrop fracture characterization using terrestrial laser scanners: deep-water Jackfork sandstone at Big Rock Quarry, Arkansas. Geosphere, 4, 237-259.

Peakall, J., McCaffrey, W.D. \& Kneller, B.C. 2000. A process model for the evolution of submarine fan channels: implications for sedimentary architecture. In: Bouma, A.H. \& Stone, C.G. (eds) Fine-grained turbidite systems. American Association of Petroleum Geologists Memoir 72/Society of Sedimentary Geology Special Publication, 68, 73-88.

Phillips, S. 1987. Dipmeter interpretation of turbidite-channel reservoir sandstones, Indian Draw Field, New Mexico. In: Tillman, R.W. \& Weber, K.J. (eds) Reservoir Sedimentation. Society of Economic Paleontologists and Mineralogists, Special Publication, 40, 113-128.

Pickering, K.T. \& Corregidor, J. 2000. 3 D reservoir-scale study of Eocene confined submarine fans, South-Central Spanish Pyrenees. In: Weimar, P., Bouma, A.H. \& Perkins, B.F. (eds) GCSSEPM Foundation, 20th Annual Research Conference Proceedings, Deep-Water Reservoirs of the World, 3-6 December, Houston, USA, $776-781$.

Pirmez, C. \& Flood, R.D. 1995. Morphology and structure of Amazon Channel. In: Flood, R.D., Piper, D.J.W., Klaus, A. \& Peterson, L.C. (eds) Proceedings of the Ocean Drilling Program, Scientific Results, 155, 23-45.

Pringle, J.K., Clark, J.D., Westerman, A.R. \& Gardiner, A.R. 2003. Using GPR to extract 3-D turbidite channel architecture from the Carboniferous
Ross Formation, County Clare, Western Ireland. In: Bristow, C.S. \& Jol, H. (eds) GPR in Sediments. Geological Society, London, Special Publications, 211, 309-320.

Pringle, J.K., Westerman, A.R., Clark, J.D. et al. 2004. 3D high-resolution digital models of outcrop analogue study sites to constrain reservoir model uncertainty: an example from Alport Castles, Derbyshire, UK. Petroleum Geoscience, 10, 343-352.

Pringle, J.K., Howell, J.A., Hodgetts, D. et al. 2006. Virtual outcrop models of petroleum reservoir outcrop analogues - a review of the current state-ofthe-art. First Break, 24, 33-42.

Pyles, D.R. 2008. Multiscale stratigraphic analysis of a structurally confined submarine fan: Carboniferous Ross Sandstone, Ireland. American Association of Petroleum Geologists Bulletin, 92, 557-587.

Samuel, A., Kneller, B., Raslan, S., Sharp, A. \& Parsons, C. 2003. Prolific deep-marine slope channels of the Nile Delta, Egypt. American Association of Petroleum Geologists Bulletin, 87, 541-560.

Satur, N., Hurst, A., Cronin, B.T. et al. 2000. Sand body geometry in a sand-rich, deep-water clastic system. Marine and Petroleum Geology, 17 239-252.

Schwab, A.M., Cronin, B.T. \& Ferreira, H. 2007. Seismic expression of channel outcrops: offset stacked versus amalgamated channel systems. Marine and Petroleum Geology, 24, 504-514.

Sgavetti, M. 1992. Criteria for stratigraphic correlation using aerial photographs: examples from the south-central Pyrenees. American Association of Petroleum Geologists Bulletin, 76, 708-730.

Sikkema, W. \& Wojcik, K.M. 2000. 3D visualisation of turbidite systems, Lower Congo Basin, offshore Angola. In: Weimar, P., Bouma, A.H. \& Perkins, B.F. (eds) GCSSEPM Foundation, 20th Annual Research Conference Proceedings, Deep-Water Reservoirs of the World, 3-6 December, Houston, USA, 928-939.

Sixsmith, P.J., Flint, S.S., Wickens, H.D. \& Johnson, S.D. 2004. Anatomy and Stratigraphic Development of a Basin Floor Turbidite System in the Laingsburg Formation, Main Karoo Basin, South Africa. Journal of Sedimentary Research, 74, 239-254.

Sprague, A.R., Sullivan, M.D., Campion, K.M. et al. 2002. The physical stratigraphy of deep-water strata; a hierarchical approach to the analysis of genetically related stratigraphic elements for improved reservoir prediction. In: American Association of Petroleum Geologists (AAPG) Annual Meeting, Expanded Abstracts, 167.

Staggs, J.G., Young, A. \& Slatt, R.M. 2003. Ground-penetrating radar facies characterization of deepwater turbidite outcrops. The Leading Edge, 22, 888-891.

Stephen, K.D., Clark, J.D. \& Gardiner, A.R. 2001. Outcrop-based stochastic modelling of turbidite amalgamation and its effects on hydrocarbon recovery. Petroleum Geoscience, 7, 163-172.

Twichell, D., Nelson, H.C., Kenyon, N. \& Schwab, W. 2009. The influence of external processes on the Holocene evolution of the Mississippi Fan. In: Kneller, B., Martinsen, O.J. \& McCaffrey, W.D. (eds) External controls on deep-water depositional systems. Society for Sedimentary Geology Special Publication, 92, 145-157.

Veevers, J.J., Cole, D.I. \& Cowan, E.J. 1994. Southern Africa: Karoo Basin and Cape Fold Belt. In: Veevers, J.J. \& Powell, C. McA. (eds) PermianTriassic Pangean Basins and Foldbelts along the Panthalassan Margin of Gondwanaland. Geological Society of America Memoir, 184, 223-279.

Visser, C.A. \& Chessa, A.G. 2000. Estimation of length distributions from outcrop datasets - application to the Upper Permian Cutler Formation, Utah. Petroleum Geoscience, 6, 29-36.

Visser, J.N.R. 1993. Sea-level changes in a back-arc-foreland transition: The Late Carboniferous-Permian Karoo Basin of South Africa. Sedimentary Geology, 83, 115-131.

Weber, K.J. 1993. The use of 3-D seismic in reservoir geological modelling. In: Flint, S.S. \& Bryant, I.D. (eds) The geological modelling of bydrocarbon reservoirs and outcrop analogues. International Association of Sedimentologists Special Publication, 15, 181-188.

White, D.W. \& Willis, B.J. 2000. A method to estimate length distributions from outcrop data. Mathematical Geology, 32, 389-419.

Wickens, H.D. 1994. Basin floor fan building turbidites of the southwestern Karoo Basin, Permian Ecca Group, South Africa. PhD thesis. University of Port Elizabeth, Port Elizabeth, South Africa.

Young, R.A., Slatt, R.M. \& Staggs, J.G. 2003. Application of ground penetrating radar imaging to deepwater (turbidite) outcrops. Marine \& Petroleum Geology, 20, 809-821.

Zanchi, A., Francesca, S., Stefano, Z., Simeone, S. \& Graziano, G. 2009. 3D reconstruction of complex geological bodies: examples from the Alps. Computers \& Geosciences, 35, 49-69. 